University of South Florida

DIGITAL COMMONS

Digital Commons @ University of

@ UNIVERSITY OF SOUTH FLORIDA

South Florida

$10-2010$

\title{
A Tremor and Slip Event on the Cocos-Caribbean Subduction Zone as measured by a Global Positioning System (GPS) and Seismic Network on the Nicoya Peninsula, Costa Rica
}

\author{
Kimberly Outerbridge \\ University of Miami \\ Timothy H. Dixon \\ University of Miami \\ Susan Y. Schwartz \\ University of California \\ Jacob I. Walter \\ University of California \\ Marino Protti \\ Universidad Nacional, Heredia \\ Follow this and additional works at: https://digitalcommons.usf.edu/geo_facpub \\ PPratopabe Eor udditionadautbonsions
}

\section{Scholar Commons Citation}

Outerbridge, Kimberly; Dixon, Timothy H.; Schwartz, Susan Y.; Walter, Jacob I.; Protti, Marino; Gonzalez, Victor; Biggs, J.; Thorwart, Martin; and Rabbel, Wolfgang, "A Tremor and Slip Event on the Cocos-Caribbean Subduction Zone as measured by a Global Positioning System (GPS) and Seismic Network on the Nicoya Peninsula, Costa Rica" (2010). School of Geosciences Faculty and Staff Publications. 433.

https://digitalcommons.usf.edu/geo_facpub/433

This Article is brought to you for free and open access by the School of Geosciences at Digital Commons @ University of South Florida. It has been accepted for inclusion in School of Geosciences Faculty and Staff Publications by an authorized administrator of Digital Commons @ University of South Florida. For more information, please contact digitalcommons@usf.edu. 


\section{Authors}

Kimberly Outerbridge, Timothy H. Dixon, Susan Y. Schwartz, Jacob I. Walter, Marino Protti, Victor Gonzalez, J. Biggs, Martin Thorwart, and Wolfgang Rabbel 


\title{
A tremor and slip event on the Cocos-Caribbean subduction zone as measured by a global positioning system (GPS) and seismic network on the Nicoya Peninsula, Costa Rica
}

\author{
Kimberly C. Outerbridge, ${ }^{1}$ Timothy H. Dixon, ${ }^{1}$ Susan Y. Schwartz, ${ }^{2}$ Jacob I. Walter, ${ }^{2}$ \\ Marino Protti, ${ }^{3}$ Victor Gonzalez, ${ }^{3}$ J. Biggs, ${ }^{1,4}$ Martin Thorwart, ${ }^{5}$ and Wolfgang Rabbel ${ }^{5}$ \\ Received 5 August 2009; revised 19 May 2010; accepted 3 June 2010; published 12 October 2010.
}

[1] In May 2007 a network of global positioning systems (GPS) and seismic stations on the Nicoya Peninsula, of northern Costa Rica, recorded a slow-slip event accompanied by seismic tremor. The close proximity of the Nicoya Peninsula to the seismogenic part of the Cocos-Caribbean subduction plate boundary makes it a good location to study such events. Several centimeters of southwest motion were recorded by the GPS stations over a period of several days to several weeks, and the seismic stations recorded three distinct episodes of tremor during the same time span. Inversion of the surface displacement data for the depth and pattern of slip on the plate interface shows peak slip at a depth of $25-30 \mathrm{~km}$, downdip of the main seismogenic zone. Estimated temperatures here are $\sim 250^{\circ}-300^{\circ} \mathrm{C}$, lower than in other subduction zones where events of this nature have been previously identified. There may also be a shallower patch of slip at $\sim 6 \mathrm{~km}$ depth. These results are significant in that they are the first to suggest that slow slip can occur at the updip transition from stick slip to stable sliding, and that a critical temperature threshold is not required for slow slip. Tremor and low-frequency earthquake locations are more difficult to determine. Our results suggest they occur on or near the plate interface at the same depth range as the deep slow slip, but not spatially colocated.

Citation: Outerbridge, K. C., T. H. Dixon, S. Y. Schwartz, J. I. Walter, M. Protti, V. Gonzalez, J. Biggs, M. Thorwart, and W. Rabbel (2010), A tremor and slip event on the Cocos-Caribbean subduction zone as measured by a global positioning system (GPS) and seismic network on the Nicoya Peninsula, Costa Rica, J. Geophys. Res., 115, B10408, doi:10.1029/2009JB006845.

\section{Introduction}

[2] Episodic tremor and slip (ETS) events are repeated, slow offsets on the subduction zone fault interface accompanied by seismic tremor. ETS events may reflect processes in the transition zone between locked and aseismically slipping portions of the subducting slab interface [Kato, 2003; Ito et al., 2007; Schwartz and Rokosky, 2007]. As in standard thrust earthquakes, the slip direction of the upper plate is opposite interseismic plate motion, recovering strain accumulated since the last slip event, but the rate of slip is orders of magnitude smaller than in earthquake ruptures. ETS events have been observed in the Cascadia subduction zone [Dragert et al., 2001; Miller et al., 2002; Melbourne et al., 2005; Brudzinski and Allen, 2007], Japan [Hirose et al.,

\footnotetext{
${ }^{1}$ Rosenstiel School of Marine and Atmospheric Science, University of Miami, Miami, Florida, USA.

${ }^{2}$ University of California, Santa Cruz, California, USA.

${ }^{3}$ Universidad Nacional, Heredia, Costa Rica.

${ }^{4}$ Now at NCEO Department of Earth Sciences, University of Oxford, Oxford, UK

${ }^{5}$ Christian-Albrechts-Universität, Kiel, Germany.

Copyright 2010 by the American Geophysical Union. 0148-0227/10/2009JB006845
}

1999; Ozawa et al., 2001; Ozawa et al., 2002; Igarashi et al., 2003; Ozawa et al., 2003; Ozawa et al., 2004; Hirose and Obara, 2005, 2006; Ito et al., 2007; Ozawa et al., 2007] and Mexico [Lowry et al., 2001; Kostoglodov et al., 2003; Larson et al., 2004; Franco et al., 2005; Brudzinski et al., 2007; Larson et al., 2007;]. New Zealand experiences slow slip without seismic tremor [Douglas et al., 2005; McCaffrey et al., 2008]. Whether or not tremor occurs, a slow-slip event increases stress updip from the locus of maximum slip, the potential rupture zone of future megathrust earthquakes [Ito et al., 2007].

[3] Slip events can last for days to weeks, e.g., 2 to $5 \mathrm{~d}$ on the Nankai subduction zone in Japan [Ito et al., 2007] and 6 to $15 \mathrm{~d}$ along the Cascadia subduction zone [Dragert et al., 2001]. Tremor originates from the same, or nearby regions [Rogers and Dragert, 2003; Kao et al., 2005; Shelly et al., 2006; Ito et al., 2007]. Both tremor and slip can repeat in quasi-regular intervals [Miller et al., 2002; Shelly et al., 2006; Brudzinski and Allen, 2007; Dragert, 2007]. Repeat times range from $14 \mathrm{mo}$ in central Cascadia [Szeliga et al., 2008] to $6 \mathrm{yr}$ in the Bungo Channel of Japan [Ozawa et al., 2004; Ozawa et al., 2007].

[4] The physical mechanism responsible for ETS events is still debated but changes in pore-fluid pressure related to dehydration reactions in subducted oceanic crust and sedi- 


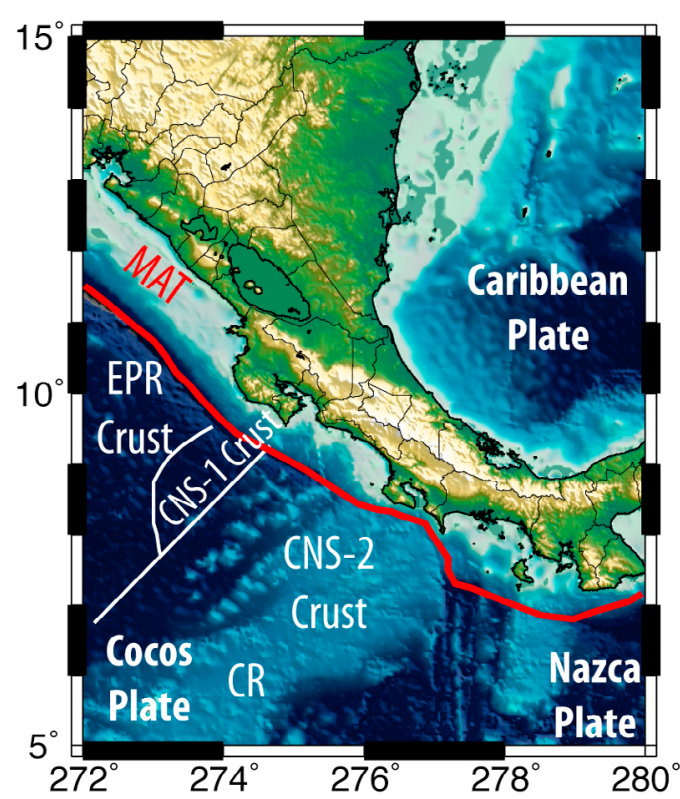

Figure 1. Regional map of Central America. Map shows variation in oceanic crust origin and topographic relief. MAT, Middle America Trench; EPR, East Pacific Rise crust; CNS, Cocos-Nazca Spreading Center crust; CR, Cocos Ridge.

mentary cover are likely involved [Shelly et al., 2006; Ito et al., 2007], with possible temperature influences [Peacock and Wang, 1999; Dragert et al., 2001; Peacock et al., 2002]. The temperature profiles of the well-studied relatively warm Japanese and Cascadia subduction zones contrast with the cooler Costa Rican system.

[5] In this paper, we describe a tremor and slip event detected in May 2007. This is the first well-documented slow-slip event along the Nicoya subduction zone, part of the Cocos-Caribbean plate boundary (Figure 1). This event was detected on a network of continuous global positioning system (GPS) and seismic stations in northern Costa Rica, which we installed from 2005-2009 (Figure 2). At this point, we do not know if such events are episodic, though preliminary evidence for other events has been presented by Protti et al. [2004] using three GPS stations and by Brown et al. [2005] using offshore fluid flow data. Tremor did occur coincident with the geodetically observed 2007 slow-slip event (Figure 3). For clarity, we refer to this as a tremor and slip event (TSE). We describe the available data constraints on location and duration of slip and tremor, and compare the locus of the 2007 TSE to past large plate boundary earthquakes in the region.

\section{Geologic Background}

[6] The Cocos and Caribbean plates are converging at high rates $\left(\sim 8-9 \mathrm{~cm} \mathrm{yr}^{-1}\right.$ in Costa Rica) with varying amounts of obliquity [DeMets, 2001]. At the latitude of the Nicoya Peninsula (Figure 1), the convergence direction is $\sim 10^{\circ}$ counter-clockwise from the trench-normal direction [DeMets et al., 1994; DeMets, 2001]. Along this segment of the Middle America Trench, between the North AmericaCocos-Caribbean triple junction [Guzman-Speziale, 2001] and the central Costa Rican deformed belt [Marshall et al., 2000], relative plate motion is partitioned. Subduction close to the trench-normal direction occurs at a rate of 74-84 \pm $5 \mathrm{~mm} \mathrm{yr}^{-1}$, while northwest-directed, arc-parallel shear occurs at rates between about $14 \pm 4 \mathrm{~mm} \mathrm{yr}^{-1}$ [DeMets, 2001] and $8 \pm 3 \mathrm{~mm} \mathrm{yr}^{-1}$ [Iinuma et al., 2004; Norabuena et al., 2004; LaFemina et al., 2009], associated with northwest motion of a fore-arc "sliver block." The southeastern end of this block probably terminates in the central Costa Rica deformed belt [LaFemina et al., 2009].

[7] Northwest Costa Rica includes a major peninsula, the Nicoya Peninsula, elongated in the northwest-southeast direction. The Nicoya Peninsula lies southwest of the active volcanic arc, and is part of the fore-arc block that undergoes slow northwest translation. The close proximity of the Nicoya Peninsula to the trench, and its position over the seismogenic zone [Protti et al., 2001; Newman et al., 2002; DeShon et al., 2003; Norabuena et al., 2004; DeShon et al., 2006], allows geodetic and seismic instrumentation to be placed close to
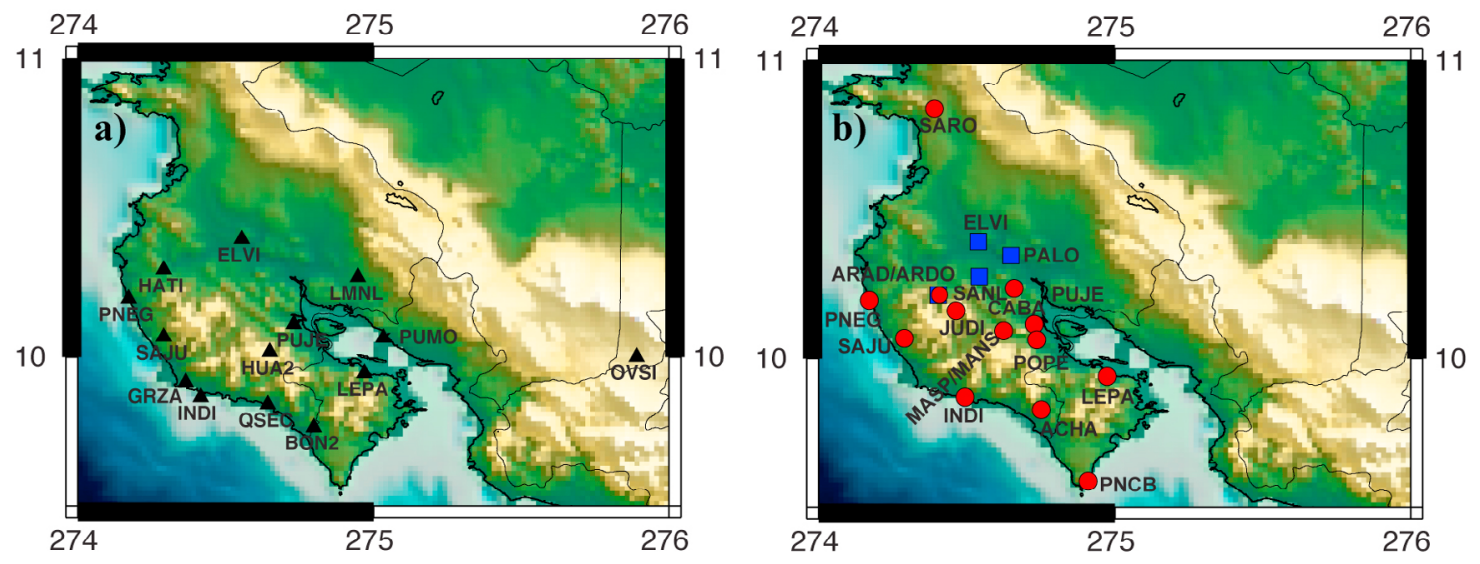

Figure 2. (a) Location of CGPS (black triangles). Note SAJU was installed after the 2007 TSE. (b) Location of seismometers; blue squares indicate $100 \mathrm{~m}$ borehole seismic vaults, red circles indicate shallow $(2-8 \mathrm{~m})$ surface seismic vaults. Note SAJU and ACHA were installed after the 2007 TSE. 

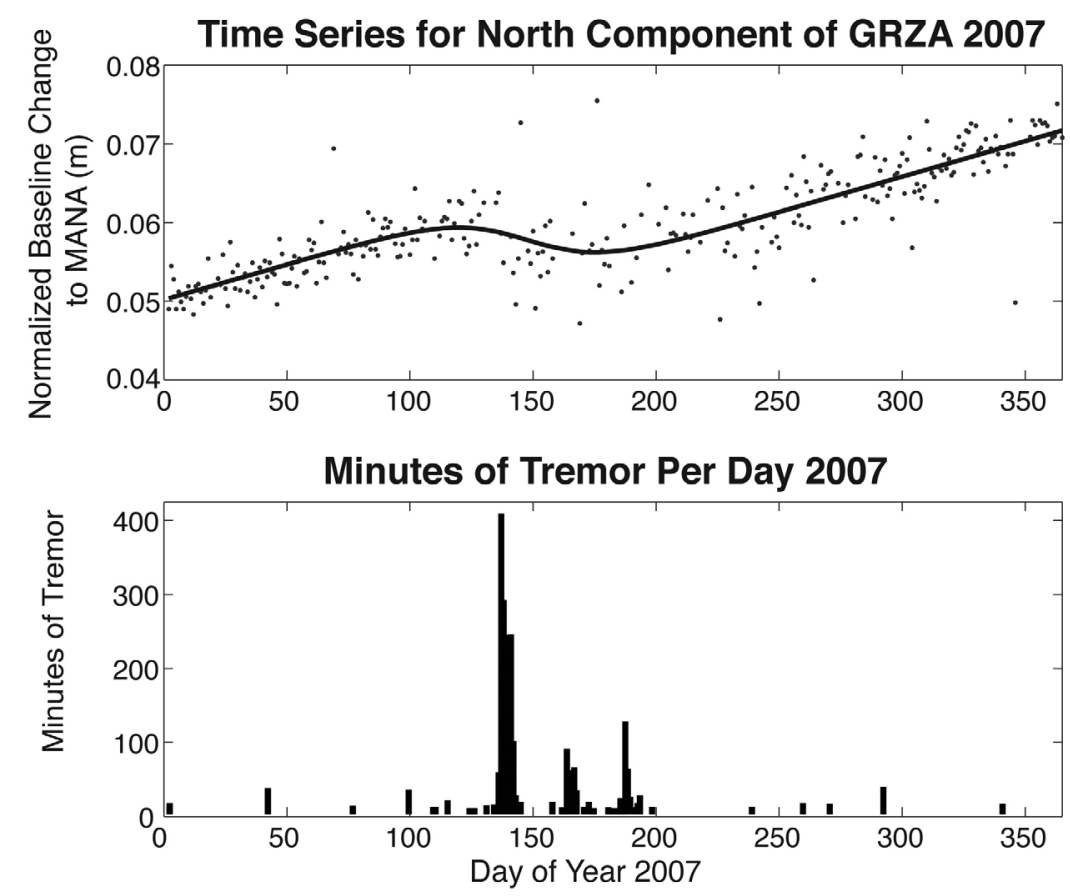

Figure 3. North component of displacement at station GRZA compared to a histogram of cumulative tremor duration per day for the entire year of 2007. Curved solid line is best fit model from Equation 1. Areas showing no tremor were analyzed and no tremor was found. The onset and duration of the geodetically determined slow slip correlates well with the peaks in the tremor time series.

the locus of strain accumulation and release, making it a good location to study seismic processes on a subduction zone plate boundary.

\section{GPS and Seismic Network}

[8] By the end of 2008, the Nicoya Peninsula had a network of 13 continuous GPS (CGPS) and 17 seismic stations (Figure 2). Most of the CGPS stations discussed here were installed between 2005 and 2008, although three stations were available in 2002 (Figure 4). The CGPS stations have varying equipment and communication capability (Table 1). Eight sites had NetRS receivers, partitioned to record both $5 \mathrm{~Hz}$ and $15 \mathrm{~s}$ data. The $5 \mathrm{~Hz}$ data may record long-period dynamic offsets associated with future large earthquakes. Remaining sites were equipped with Trimble 5700 receivers. The network was complete by late 2009 , with a total of 19 CGPS and 17 seismic sites operating on or near the Nicoya Peninsula, including two reference stations outside the deforming region. These are used to reduce the effect of

\section{Network Data Coverage}

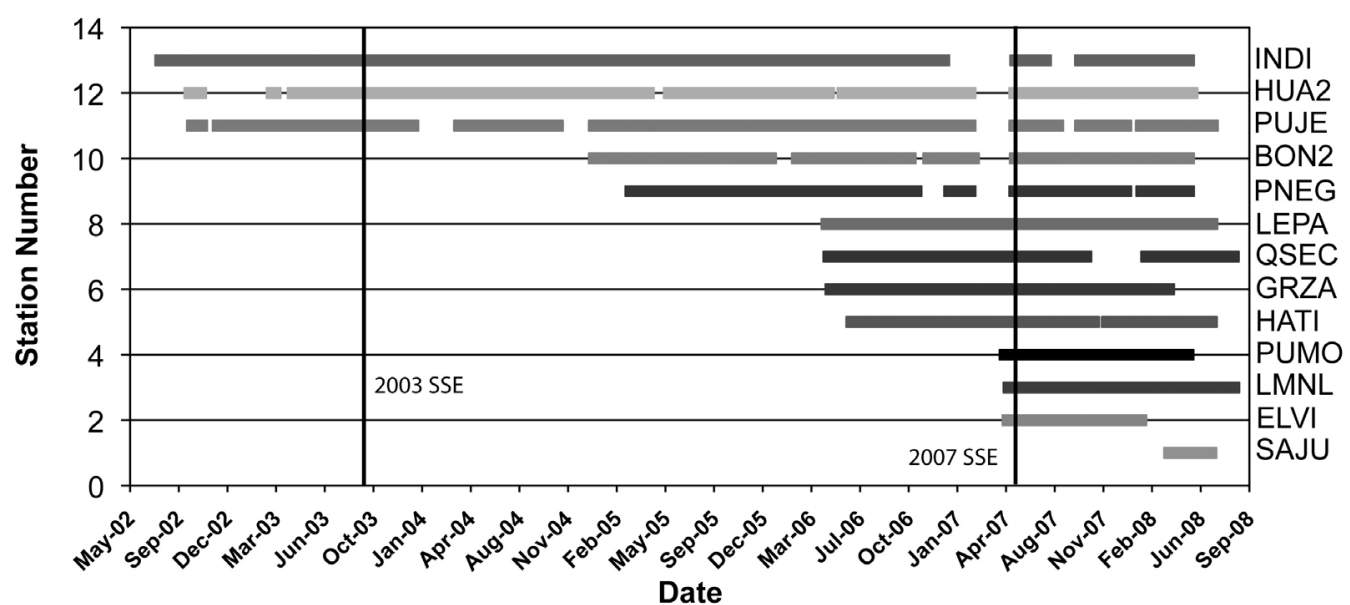

Figure 4. Timing of CGPS station installation and data availability. The 2003 SSE and 2007 TSE are marked for reference. 
Table 1. Nicoya CGPS Station Specifications

\begin{tabular}{|c|c|c|c|c|c|c|}
\hline Site Name & Latitude & Longitude & Receiver Type & Antenna Type & Communications & Monument Type \\
\hline BON2 & 9.764 & -85.203 & Trimble 5700 & Zephyr with Ground plane & Manual Download & Concrete Pier $^{\mathrm{a}}$ \\
\hline ELVI & 10.394 & -85.446 & Trimble NetRS & Chokering with Raydome & Cell/Internet & Shallow Monument ${ }^{\mathrm{b}}$ \\
\hline GRZA & 9.915 & -85.636 & Trimble NetRS & Chokering with Raydome & Cell & Shallow Monument ${ }^{\mathrm{b}}$ \\
\hline HATI & 10.291 & -85.710 & Trimble NetRS & Chokering with Raydome & Manual Download & Shallow Monument ${ }^{\mathrm{b}}$ \\
\hline HUA2 & 10.017 & -85.352 & Trimble 5700 & Zephyr with Ground plane & Manual Download & Concrete Pier $^{\mathrm{a}}$ \\
\hline INDI & 9.864 & -85.585 & Trimble 5700 & Zephyr with Ground plane & Manual Download & Concrete Pier ${ }^{\mathrm{a}}$ \\
\hline LEPA & 9.945 & -85.031 & Trimble NetRS & Chokering with Raydome & Cell & Deep Monument $^{\mathrm{c}}$ \\
\hline LMNL & 10.268 & -85.053 & Trimble NetRS & Chokering with Raydome & Cell/Internet & Shallow Monument ${ }^{\mathrm{b}}$ \\
\hline PNEG & 10.195 & -85.829 & Trimble 5700 & Zephyr with Ground plane & Manual Download & Concrete Pier ${ }^{\mathrm{a}}$ \\
\hline PUMO & 10.064 & -84.967 & Trimble NetRS & Chokering with Raydome & Manual Download & Shallow Monument ${ }^{\mathrm{b}}$ \\
\hline PUJE & 10.110 & -85.270 & Trimble 5700 & Zephyr with Ground plane & Manual Download & Concrete Pier $^{\mathrm{a}}$ \\
\hline QSEC & 9.840 & -85.357 & Trimble NetRS & Chokering with Raydome & Cell & Deep Monument $^{\mathrm{c}}$ \\
\hline SAJU & 10.067 & -85.711 & Trimble NetRS & Chokering with Raydome & Manual Download & Shallow Monument ${ }^{\mathrm{b}}$ \\
\hline
\end{tabular}

${ }^{\mathrm{a} C}$ Concrete pier monument: Rebar-reinforced concrete pillar reaching depths of 4-5 $\mathrm{m}$ with a $15 \mathrm{~cm}$ stainless steel pin set in the center. Antennae INDI and PUJE are set on spike mounts about the monument pin. The antenna at PNEG is threaded directly onto the pin in the pier.

${ }^{\mathrm{b}}$ Shallow PBO style monument: 4 legs (tripod and center pole) anchored at $\sim 1.5 \mathrm{~m}$ depth in the presence of bedrock.

${ }^{\mathrm{c}}$ Deep PBO style monument: 5 legs (quadrapod and center pole) anchored at $10-12 \mathrm{~m}$ in the absence of bedrock.

common-mode errors, for example due to orbit and atmospheric effects, important for recording slow-slip events, which may have very small displacements. Unfortunately, during the May 2007 TSE, only one reference station had been installed and it was offline, rendering data for this event noisier than current data.

[9] For data transfer, two sites are directly connected to the Internet through a router for direct access. These sites, LMNL, located in Limonal, and ELVI in Hacienda el Viejo, Filadelfia, are monitored with Plate Boundary Observatory (PBO) network protocols by personnel at University NAVSTAR Consortium, Boulder, Colorado (UNAVCO), with all of the quality and systems checks that this implies. These data are available in near real time. Five sites are equipped with SIM cards and modems for data download via cellular telephone. These data are generally available within a few days of data collection. Data from remaining sites are downloaded manually, typically every few months, weather permitting (heavy rainfall during the rainy season may precludes access to some of the more remote sites).

[10] The seismic network was deployed in stages between 2006 and 2008 and at the time of the event consisted of 10 broadband and seven short-period stations. Tremor signals are very low amplitude and difficult to study with surface instrumentation given typical noise levels. The most common source of 1-10 Hz seismic noise arises from human activity or wind coupling into the Earth. These noise sources attenuate with depth, hence seismometers located below the surface experience significant noise reduction. Our seismic network included nine shallow ( $<5 \mathrm{~m}$ deep) vault stations (three short period and six broadband) as well as four short-period seismometers deployed in $100 \mathrm{~m}$ boreholes and four broadband sensors in $5 \mathrm{~m}$ deep vaults. Several of the seismic and GPS stations are colocated. Because of the high seismic sample rates (50-100 sps), these data are manually downloaded approximately once every $6-8 \mathrm{wk}$.

\section{Data and Analysis}

\subsection{GPS Analysis}

[11] GPS data were processed using GIPSY version 4.04 precise point positioning software developed at the Jet Pro- pulsion Laboratory, Pasadena, California (JPL) [Zumberge et al., 1997] with satellite and clock files from JPL, using procedures similar to Sella et al. [2002]. Phase ambiguity resolution was performed using the algorithm AmbiZAP [Blewitt and Kreemer, 2007; Blewitt, 2008]. Baselines from each station to site MANA in Managua, Nicaragua, approximately $250 \mathrm{~km}$ north of the Nicoya network, were calculated to reduce common-mode errors. Data from MANA are somewhat noisy during the study period, and this procedure introduces some noise into the solutions. However, the noise is mainly white in character, and should not introduce significant systematic bias. The position time series are shown in Figure 5, organized in three groups by distance from the coast (coastal, mid-peninsula and inland stations) and ordered within each group by latitude, from north to south. We did not include the vertical component in our models because of high noise levels.

\subsection{Slow-Slip Event Analysis}

[12] Characterization of the slow-slip event in the GPS time series was performed using the hyperbolic tangent model of Larson et al. [2004]. This five-parameter model includes the integral characterization variables; initial position $\left(x_{0}\right)$, the background site velocity $(V)$, assumed to be constant before and after the event, the event offset $(U)$, the midpoint time of the event $(T)$, and duration half width $(\tau)$ (Figure 6):

$$
X(t)=x_{0}+V t+\frac{U}{2}\left[\tanh \frac{t-T}{\tau}-1\right]
$$

The model is fit to the data by nonlinear regression and least squares techniques. Residuals and confidence intervals are also estimated during the least squares analysis.

[13] For time series with low signal-to-noise ratios, simultaneous estimation of all five parameters is not possible, although event offset $U$ is usually clear even in stations with low signal-to-noise ratios, e.g., HATI (Figure 6). For these time series, we estimated parameters iteratively, as follows. In baseline time series with a high signal-to-noise ratio and a clear representation of the slip event, we first loosely defined the event timing (duration half width $\tau$ and event midpoint $T$ ), 

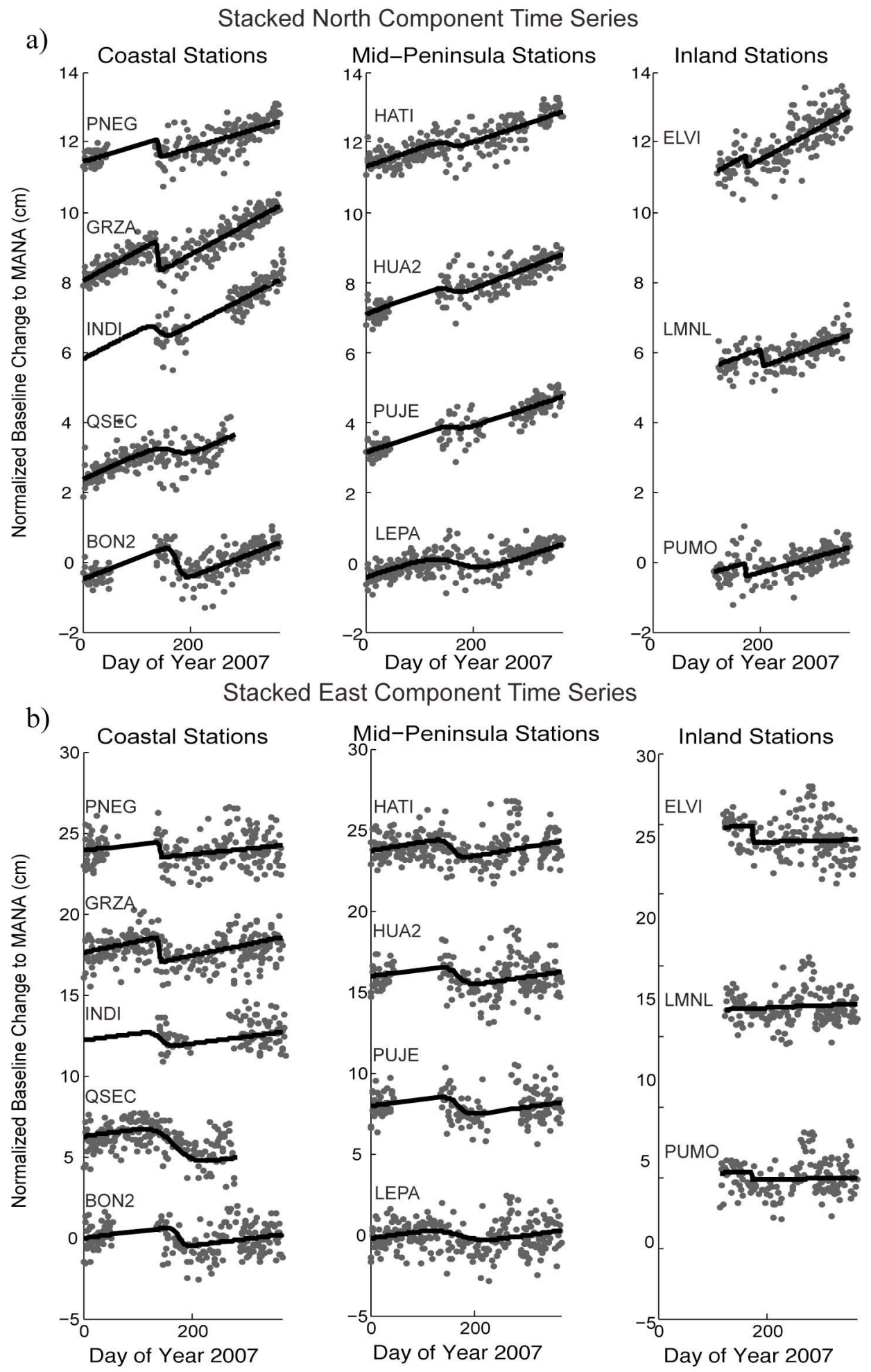

Figure 5. Baseline time series relative to station MANA. Stations are organized in three groups by longitude and within each group by latitude. All fits use station-optimized timing parameters. (a) Time series for the North component of the CGPS stations. (b) Time series for the East component of the CGPS stations.

then estimated $U$ and $V$, and finally refined the estimates for $T$ and $\tau$.

[14] The length of the time series used to determine background velocity $V$ was as long as possible, taking into account equipment installation, removing data from a possible slowslip event in 2003 [Protti et al., 2004], considering monument settling time, and a conservative temporal window in which the 2007 TSE may have occurred. Velocities were 


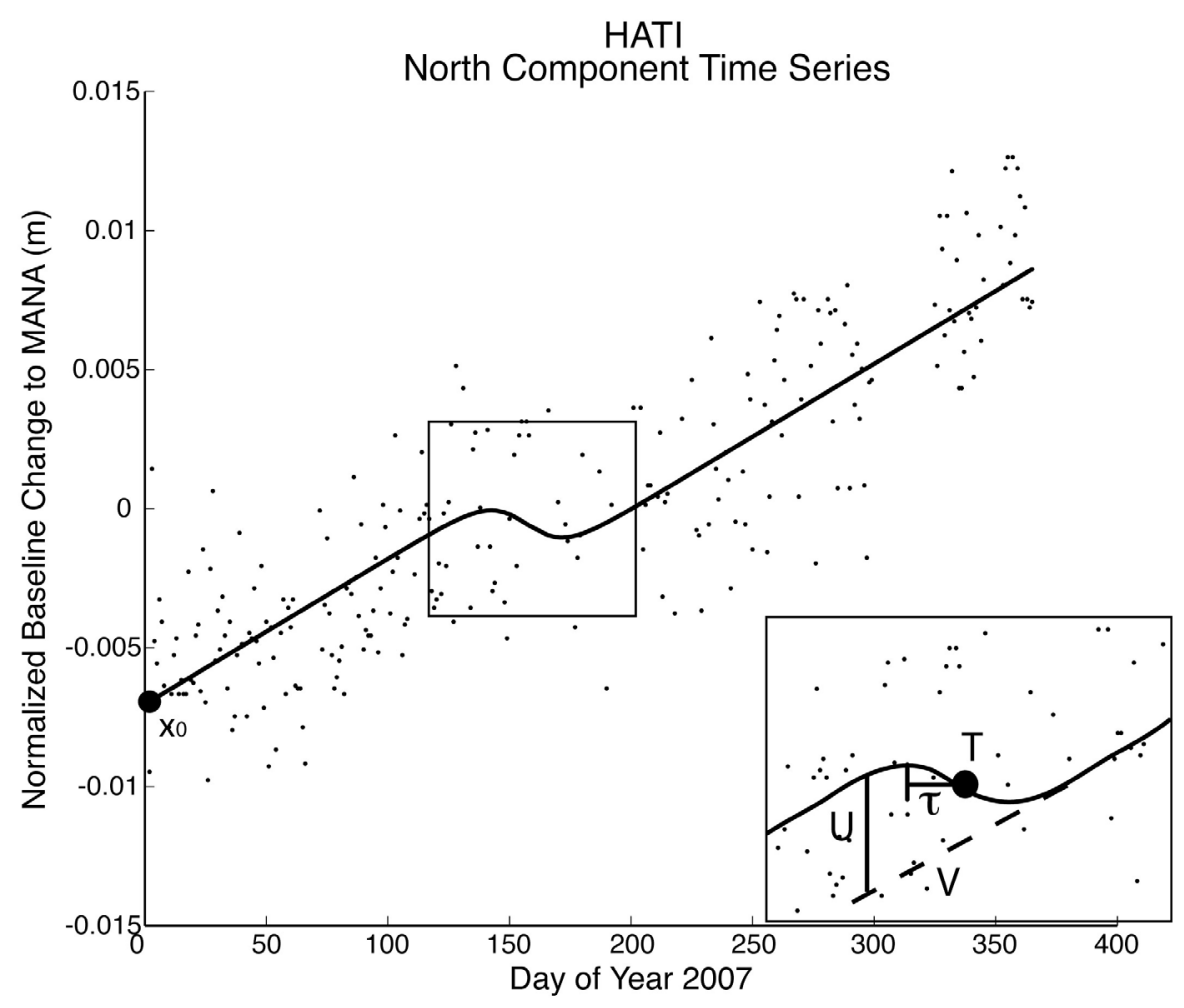

Figure 6. North component of station HATI with best-fit model, annotated with model parameters. Although station has relatively poor signal-to-noise ratio (Table $2 \mathrm{a}$ ), the offset $U$ is still clearly defined. See section 4.2 for definition of parameters.

estimated separately for both the north and east components at each station. This provides an adjusted interseismic velocity relative to the reference station (Figure 5) which can be rotated to define velocities relative to the stable Caribbean Plate [DeMets, 2001] (Figure 7). Deviation of these interseismic velocities from the plate convergence direction primarily reflects forearc sliver transport [Lundgren et al., 1999; DeMets, 2001; Iinuma et al., 2004; Norabuena et al., 2004; LaFemina et al., 2009]. Uncertainties for the velocity estimates (Table 2) were calculated following the formulations of Dixon et al. [2000] and Mao et al. [1999].

[15] Once the interseismic velocity is well established, other parameters are iteratively estimated using two different approaches. In the first approach, best fit estimates for all parameters are obtained, requiring only the timing parameters $(T$ and $\tau)$ are the same for both $(\mathrm{N}, \mathrm{E})$ horizontal components at each station. This allows timing parameters to vary between stations, e.g., to investigate possible migration of slip. The combined chi squared misfits of the north and east components were minimized to identify the best fitting parameters. These are referred to as station-optimized fits (Table 2a; Figure 5). Figure 7 shows the corresponding offsets and interseismic velocities in map view.

[16] One weakness of this approach is that event timing $(T, \tau)$ is poorly defined for stations with poor signal-to-noise ratio and this may affect the offset estimates. We therefore used a second approach, fixing the timing parameters, $T$ and $\tau$, to average values (2007 day of year 160 and 20 days respectively) based on seven stations where the event is well defined and signal-to-noise ratio is high. These fits will be

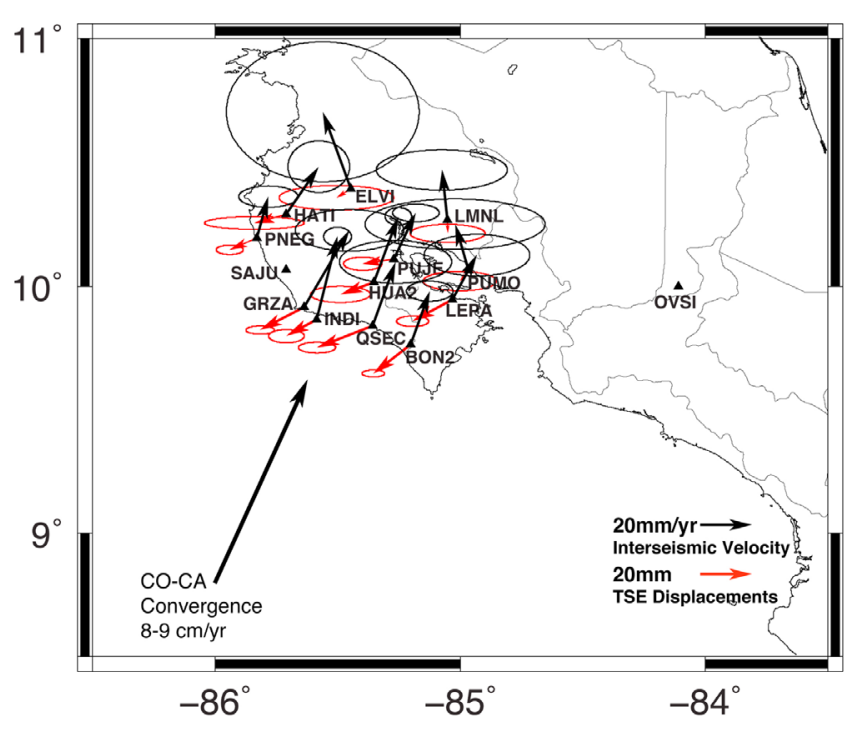

Figure 7. Adjusted interseismic velocity vectors relative to stable Caribbean plate (black vectors and black 95\% confidence ellipses); and the best-fitting surface displacements for the 2007 TSE (red vectors and red 95\% confidence ellipses). Velocities based on station-optimized fits to GPS data. 
Table 2a. Station-Optimized Hyperbolic Tangent Model Fits ${ }^{\mathrm{a}}$

\begin{tabular}{|c|c|c|c|c|c|c|c|c|c|}
\hline Site & $\mathrm{N} / \mathrm{E}$ & $\mathrm{V}(\mathrm{mm} / \mathrm{yr})$ & $\mathrm{U}(\mathrm{mm})$ & T $2007 \mathrm{DOY}^{\mathrm{b}}$ & $\begin{array}{c}\text { Start Day } \\
2007 \mathrm{DOY}^{\mathrm{b}}\end{array}$ & Tau (days) & $\begin{array}{l}\text { Duration } \\
\text { (days) }\end{array}$ & $\begin{array}{c}\text { WRMS }^{\mathrm{c}} \\
(\mathrm{mm})\end{array}$ & $\begin{array}{l}\text { Signal-To- } \\
\text { Noise Ratio }\end{array}$ \\
\hline \multirow[t]{2}{*}{ BON2 } & $\mathrm{N}$ & $21.4 \pm 1.6$ & $-11.2 \pm 0.6$ & $176 \pm 1.5$ & 165.0 & $11.0 \pm 3.5$ & 22 & 3.0 & 3.8 \\
\hline & $\mathrm{E}$ & $15.2 \pm 3.7$ & $-14.4 \pm 1.8$ & $176 \pm 13.0$ & 165.0 & $11.0 \pm 27.0$ & 22 & 8.7 & 1.7 \\
\hline \multirow[t]{2}{*}{ ELVI } & $\mathrm{N}$ & $30.5 \pm 11.1$ & $-3.5 \pm 2.0$ & $174 \pm \mathrm{UC}^{\mathrm{d}}$ & 173.5 & $0.5 \pm \mathrm{UC}^{\mathrm{d}}$ & 1 & 3.9 & 0.9 \\
\hline & $\mathrm{E}$ & $-3.2 \pm 15.3$ & $-5.6 \pm 9.1$ & 174 (fixed) & 173.5 & 0.5 (fixed) & 1 & 12.8 & 0.4 \\
\hline \multirow[t]{2}{*}{ GRZA } & $\mathrm{N}$ & $30.6 \pm 3.3$ & $-8.9 \pm 0.7$ & $140 \pm 7.0$ & 137.0 & $3.0 \pm 12.0$ & 6 & 2.6 & 3.4 \\
\hline & $\mathrm{E}$ & $25.3 \pm 8.6$ & $-17.2 \pm 2.3$ & $140 \pm 8.5$ & 137.0 & $3.0 \pm 13.0$ & 6 & 8.6 & 2.0 \\
\hline \multirow[t]{2}{*}{ HATI } & $\mathrm{N}$ & $19.1 \pm 4.1$ & $-3.5 \pm 1.0$ & $157 \pm 23.5$ & 141.0 & $16.0 \pm 48.5$ & 32 & 2.8 & 1.3 \\
\hline & $\mathrm{E}$ & $20.4 \pm 4.9$ & $-12.4 \pm 7.9$ & 157 (fixed) & 141.0 & 16.0 (fixed) & 32 & 8.3 & 1.5 \\
\hline \multirow[t]{2}{*}{ HUA2 } & $\mathrm{N}$ & $21.9 \pm 1.4$ & $-4.8 \pm 1.3$ & $167 \pm 19.5$ & 147.0 & $20.0 \pm 30.0$ & 40 & 2.7 & 1.8 \\
\hline & $\mathrm{E}$ & $17.2 \pm 2.1$ & $-13.0 \pm 4.8$ & $167 \pm 13.5$ & 147.0 & $20.0 \pm 29.5$ & 40 & 9.4 & 1.4 \\
\hline \multirow[t]{2}{*}{ INDI } & $\mathrm{N}$ & $29.0 \pm 1.5$ & $-6.4 \pm 1.1$ & $143 \pm 43.0$ & 128.0 & $15.0 \pm 111.5$ & 30 & 2.9 & 2.2 \\
\hline & $\mathrm{E}$ & $15.8 \pm 2.2$ & $-11.8 \pm 2.9$ & $143 \pm 12.5$ & 128.0 & $15.0 \pm 27.0$ & 30 & 9.1 & 1.3 \\
\hline \multirow[t]{2}{*}{ LEPA } & $\mathrm{N}$ & $18.0 \pm 3.3$ & $-8.3 \pm 0.9$ & $171 \pm 15.0$ & 127.0 & $44.0 \pm 24.2$ & 88 & 3.8 & 2.2 \\
\hline & $\mathrm{E}$ & $17.2 \pm 8.4$ & $-15.5 \pm 2.6$ & $171 \pm 14.0$ & 127.0 & $44.0 \pm 29.5$ & 88 & 9.3 & 1.7 \\
\hline \multirow[t]{2}{*}{ LMNL } & $\mathrm{N}$ & $20.2 \pm 3.2$ & $-5.2 \pm 1.5$ & $204 \pm 19.0$ & 203.5 & $0.5 \pm 19.0$ & 1 & 2.9 & 1.8 \\
\hline & $\mathrm{E}$ & $5.6 \pm 10.4$ & $0.2 \pm 6.0$ & 204 (fixed) & 203.5 & 0.50 (fixed) & 1 & 10.6 & 0.0 \\
\hline \multirow[t]{2}{*}{ PNEG } & $\mathrm{N}$ & $16.7 \pm 1.7$ & $-4.6 \pm 0.8$ & $142 \pm 11.5$ & 140.0 & $2.0 \pm 22.5$ & 4 & 2.9 & 1.6 \\
\hline & $\mathrm{E}$ & $12.1 \pm 4.7$ & $-10.6 \pm 2.2$ & $142 \pm 12.0$ & 140.0 & $2.0 \pm 21.5$ & 4 & 9.4 & 1.1 \\
\hline \multirow[t]{2}{*}{ PUJE } & $\mathrm{N}$ & $18.6 \pm 1.4$ & $-1.8 \pm 1.1$ & 168 (fixed) & 150.0 & 18.0 (fixed) & 36 & 2.7 & 0.7 \\
\hline & $\mathrm{E}$ & $16.2 \pm 3.7$ & $-12.1 \pm 3.1$ & $168 \pm 22.0$ & 150.0 & $18.0 \pm 41.0$ & 36 & 8.8 & 1.4 \\
\hline \multirow[t]{2}{*}{ PUMO } & $\mathrm{N}$ & $15.7 \pm 4.0$ & $-4.2 \pm 1.6$ & $173 \pm 9.5$ & 172.5 & $0.5 \pm 14.0$ & 1 & 2.9 & 1.5 \\
\hline & $\mathrm{E}$ & $2.5 \pm 14.3$ & $-3.3 \pm 5.8$ & $173 \pm U^{d}$ & 172.5 & $0.5 \pm \mathrm{UC}^{\mathrm{d}}$ & 1 & 10.4 & 0.3 \\
\hline \multirow[t]{2}{*}{ QSEC } & $\mathrm{N}$ & $25.5 \pm 3.4$ & $-8.5 \pm 0.9$ & $168 \pm 15.0$ & 136.0 & $32.0 \pm 21.0$ & 64 & 2.9 & 2.9 \\
\hline & $\mathrm{E}$ & $16.6 \pm 8.9$ & $-21.6 \pm 3.0$ & $168 \pm 14.0$ & 136.0 & $32.0 \pm 33.0$ & 64 & 8.6 & 2.5 \\
\hline
\end{tabular}

${ }^{\mathrm{a}}$ Parameters defined in section 4.2 .

${ }^{\mathrm{b}}$ Julian Day.

${ }^{\mathrm{c}}$ Weighted Root Mean Square.

${ }^{\mathrm{d}}$ Unconstrained.

${ }^{\text {e}}$ Signal-to-noise ratio is the surface motion (U) divided by the wrms.

Table 2b. Network-Optimized Hyperbolic Tangent Model Fits ${ }^{\mathrm{a}}$

\begin{tabular}{|c|c|c|c|c|c|c|c|c|}
\hline Site & $\mathrm{N} / \mathrm{E}$ & $\mathrm{V}(\mathrm{mm} / \mathrm{yr})$ & $\mathrm{U}(\mathrm{mm})$ & $\begin{array}{l}\text { T } 2007 \\
\text { DOY }^{b} \\
\text { (fixed) }\end{array}$ & $\begin{array}{c}\text { Start Day } \\
2007 \mathrm{DOY}^{\mathrm{b}} \\
\text { (fixed) }\end{array}$ & $\begin{array}{c}\text { Tau } \\
\text { (days) }\end{array}$ & $\begin{array}{c}\text { Duration } \\
\text { (days) }\end{array}$ & $\begin{array}{r}\text { WRMS } \\
(\mathrm{mm})\end{array}$ \\
\hline \multirow[t]{2}{*}{ BON2 } & $\mathrm{N}$ & $21.4 \pm 1.6$ & $-11.1 \pm 0.6$ & 160 & 140 & 20.0 & 40.0 & 3.0 \\
\hline & $\mathrm{E}$ & $15.2 \pm 3.7$ & $-14.6 \pm 1.9$ & 160 & 140 & 20.0 & 40.0 & 8.7 \\
\hline \multirow[t]{2}{*}{ ELVI } & $\mathrm{N}$ & $30.5 \pm 11.1$ & $-4.4 \pm 2.5$ & 160 & 140 & 20.0 & 40.0 & 3.9 \\
\hline & $\mathrm{E}$ & $-2.3 \pm 15.3$ & $-8.1 \pm 14.0$ & 160 & 140 & 20.0 & 40.0 & 12.7 \\
\hline \multirow[t]{2}{*}{ GRZA } & $\mathrm{N}$ & $30.6 \pm 3.3$ & $-9.0 \pm 0.7$ & 160 & 140 & 20.0 & 40.0 & 2.8 \\
\hline & $\mathrm{E}$ & $25.3 \pm 8.6$ & $-17.4 \pm 2.4$ & 160 & 140 & 20.0 & 40.0 & 8.6 \\
\hline \multirow[t]{2}{*}{ HATI } & $\mathrm{N}$ & $19.1 \pm 4.1$ & $-5.5 \pm 0.8$ & 160 & 140 & 20.0 & 40.0 & 3.2 \\
\hline & $\mathrm{E}$ & $5.0 \pm 4.9$ & $-5.4 \pm 5.8$ & 160 & 140 & 20.0 & 40.0 & 8.6 \\
\hline \multirow[t]{2}{*}{ HUA2 } & $\mathrm{N}$ & $21.9 \pm 1.4$ & $-4.7 \pm 1.4$ & 160 & 140 & 20.0 & 40.0 & 2.7 \\
\hline & $\mathrm{E}$ & $17.2 \pm 2.1$ & $-3.8 \pm 5.3$ & 160 & 140 & 20.0 & 40.0 & 9.4 \\
\hline \multirow[t]{2}{*}{ INDI } & $\mathrm{N}$ & $29.0 \pm 1.5$ & $-6.4 \pm 1.0$ & 160 & 140 & 20.0 & 40.0 & 3.0 \\
\hline & $\mathrm{E}$ & $15.8 \pm 2.2$ & $-11.9 \pm 2.9$ & 160 & 140 & 20.0 & 40.0 & 9.1 \\
\hline \multirow[t]{2}{*}{ LEPA } & $\mathrm{N}$ & $18.0 \pm 3.3$ & $-8.0 \pm 0.9$ & 160 & 140 & 20.0 & 40.0 & 3.8 \\
\hline & $\mathrm{E}$ & $17.2 \pm 8.4$ & $-15.4 \pm 2.5$ & 160 & 140 & 20.0 & 40.0 & 9.2 \\
\hline \multirow[t]{2}{*}{ LMNL } & $\mathrm{N}$ & $20.2 \pm 3.2$ & $-6.7 \pm 2.4$ & 160 & 140 & 20.0 & 40.0 & 3.0 \\
\hline & $\mathrm{E}$ & $5.6 \pm 10.4$ & $-7.2 \pm 9.3$ & 160 & 140 & 20.0 & 40.0 & 10.4 \\
\hline \multirow[t]{2}{*}{ PNEG } & $\mathrm{N}$ & $16.7 \pm 1.7$ & $-4.6 \pm 0.7$ & 160 & 140 & 20.0 & 40.0 & 2.9 \\
\hline & $\mathrm{E}$ & $12.1 \pm 4.7$ & $-10.8 \pm 2.2$ & 160 & 140 & 20.0 & 40.0 & 9.4 \\
\hline \multirow[t]{2}{*}{ PUJE } & $\mathrm{N}$ & $18.6 \pm 1.4$ & $-1.8 \pm 1.1$ & 160 & 140 & 20.0 & 40.0 & 2.7 \\
\hline & $\mathrm{E}$ & $16.2 \pm 3.7$ & $-12.2 \pm 3.1$ & 160 & 140 & 20.0 & 40.0 & 8.8 \\
\hline \multirow[t]{2}{*}{ PUMO } & $\mathrm{N}$ & $15.7 \pm 4.0$ & $-4.7 \pm 1.9$ & 160 & 140 & 20.0 & 40.0 & 2.9 \\
\hline & $\mathrm{E}$ & $2.5 \pm 14.3$ & $-20.4 \pm 7.5$ & 160 & 140 & 20.0 & 40.0 & 10.6 \\
\hline \multirow[t]{2}{*}{ QSEC } & $\mathrm{N}$ & $25.5 \pm 3.4$ & $-8.2 \pm 0.9$ & 160 & 140 & 20.0 & 40.0 & 2.9 \\
\hline & $\mathrm{E}$ & $16.6 \pm 8.9$ & $-21.2 \pm 2.9$ & 160 & 140 & 20.0 & 40.0 & 8.7 \\
\hline
\end{tabular}

${ }^{\mathrm{a}}$ Parameters defined in section 4.2 .

bulian Day.

${ }^{\mathrm{c}}$ Weighted Root Mean Square. 
referred to as network-optimized fits (Table 2b). For stations with high data noise, timing parameters were constrained using the best-fit estimate from the least noisy component, i.e., we assume that event timing must be the same in the north and east components. This was done for HATI, ELVI, LMNL, and PUJE. For noisy time series where parameter fits were performed iteratively, we checked that the offset estimates were not sensitive to the choice of initial conditions. Displacement estimates from the two approaches are very similar.

[17] It is evident from Tables $2 \mathrm{a}$ and $2 \mathrm{~b}$ that the offset $(U)$ and velocity $(V)$ parameters are better constrained than the duration $(2 \tau)$ and midpoint of the event $(T)$. This can be understood in terms of a simple white noise model, whereby parameter uncertainty scales as $1 / \sqrt{ } \mathrm{n}$, where $n$ is the number of data. As the length of the time series increases, the estimates of $V$ and $U$ improve because the number of data points used to constrain these parameters increases. In general, stations installed in the first (2002) and second (2005) phases have lower uncertainties in $V$ and $U$ compared to stations installed later. However, the duration of the event is limited compared to the total length of the time series. Hence, the parameters $T$ and $\tau$ tend to have larger relative uncertainties, as the number of data available to constrain them (typically $20-40$ ) is small. Thus, the uncertainties for $T$ and $\tau$ will not depend on station installation time, and to a first approximation will not improve with increased observation time (improving the velocity uncertainty does have some effect on the uncertainties for $T$ and $\tau$, but the effect is small). For some stations there were data outages around the event, further limiting resolution of the timing parameters. Some stations (PUMO, LMNL, and ELVI) came on-line near the beginning of the event (Figure 4), hence their duration estimates can be considered minimum estimates.

[18] One assumption of the hyperbolic tangent model is that the interseismic velocity is the same before and after the slow-slip event. Testing this assumption will require longer time series and will be addressed in future studies.

[19] Given the data noise, it is useful to ask whether a standard earthquake model, with an instantaneous offset, would fit the GPS time series adequately. The fact that no earthquake was recorded at this time, and that there was a finite period of tremor coincident with the slow-slip event, strongly suggests that the slow-slip model is appropriate. To confirm this, we performed an F-test, comparing a simple earthquake model (four variable parameters, fixing event duration in the hyperbolic tangent model to $1 \mathrm{~d}$ ) to the standard hyperbolic tangent model with five variable parameters. The results of this test suggest that for most stations, including those with low signal-to-noise ratios, the slow-slip model is warranted at better than $95 \%$ confidence. For stations with high signal-to-noise ratios (e.g., QSEC), the slow-slip model is warranted at better than $99 \%$ confidence.

\subsection{Seismic Tremor}

[20] Tremor differs from tectonic earthquakes in its very long duration, lack of impulsive seismic arrivals, and low dominant frequencies $(\sim 2-6 \mathrm{~Hz})$. These characteristics make tremor challenging to detect and locate. In southwest Japan and Cascadia, tremor has been identified by the coincidence of high amplitude envelopes on several nearby stations [e.g., Obara, 2002; McClausland et al., 2005; Wech and Creager,
2008] and in Mexico by synchronous episodes of high spectral amplitude signal in the $1-8 \mathrm{~Hz}$ range lasting minutes to hours [Payero et al., 2008]. Higher amplitudes on horizontal components and particle motions indicate that S-waves dominate tremor energy. Tremor episodes are commonly located by cross-correlation of station envelopes to obtain relative delay times that are used as S-wave arrival times in standard earthquake location algorithms. Although locations obtained in this manner identify the source volume generating tremor (with horizontal errors $\sim 10-20 \mathrm{~km}$ and depth errors approximately two to three times larger) and can reveal general migration patterns, they are usually not accurate enough to determine whether tremor activity is localized to the subducting plate interface or how tremor locations relate to frictional properties of the interface.

[21] In southwest Japan, impulsive arrivals embedded in tremor have been cataloged by the Japan Meteorological Agency as low-frequency earthquakes (LFEs). Shelly et al. [2007a, 2007b] used LFEs in this catalog as template events to search tremor signals for matching waveforms and found that tremor consists of a sequence of LFEs. Using an autocorrelation method to identify LFEs when no catalog existed, Brown et al. [2008]; Brown et al. [2009] established that tremor episodes accompanying slow slip in southwest Japan, Cascadia, and northern Costa Rica can all be explained by a nearly continuous sequence of LFEs occurring on or near the plate interface. Because of the identification of $\mathrm{P}$ and $S$ phases, the location accuracy of LFEs is several orders of magnitude better than that obtained for tremor episodes from envelope cross-correlation. However, LFE identification and location is computationally intensive, making it impractical to apply to months of seismic data.

[22] For the Nicoya Peninsula, seismometer data was visually inspected for the entire year of 2007. Tremor episodes were identified from envelopes constructed from the east-west component of ground motion filtered in the $2-6 \mathrm{~Hz}$ band. We estimated locations of tremor episodes occurring over a 1 wk period during the May 2007 slow-slip event and compared them to accurate LFE locations embedded within $3 \mathrm{hr}$ of tremor recorded on 17 May 2007, during the most energetic tremor episode of the slow-slip event. Figure 8 shows two different hours of tremor recorded at three to four borehole stations (ELVI, PALO, SANL, and ARAD), one deep vault (ARDO) and several surface stations on 17 May hour 1 (Figure 8a) and 21 May hour 4 (Figure 8b) 2007, during the middle of the slow-slip event. Coherent tremor bursts can be tracked at stations located over $50 \mathrm{~km}$ apart but are not always apparent at stations farther from the network center (LEPA and PNCB to the southeast and SARO to the northwest). Figure 3 shows cumulative minutes of tremor per day versus day of year, compared to the time series of the north component of GPS station GRZA, for the year 2007, indicating a strong peak in tremor activity between 17 and 22 May, roughly corresponding to the middle of the slow-slip event.

[23] Approximate locations of tremor episodes recorded between 17 and 22 May were obtained by cross-correlating their envelopes with a reference station and using relative time differences as $\mathrm{S}$ wave arrival times in Hypoinverse2000 [Klein, 2007]. Fifty-two tremor episodes with horizontal location errors less than $10 \mathrm{~km}$ are shown in Figure 9. Also plotted on this figure are 232 LFEs that were detected 
a)

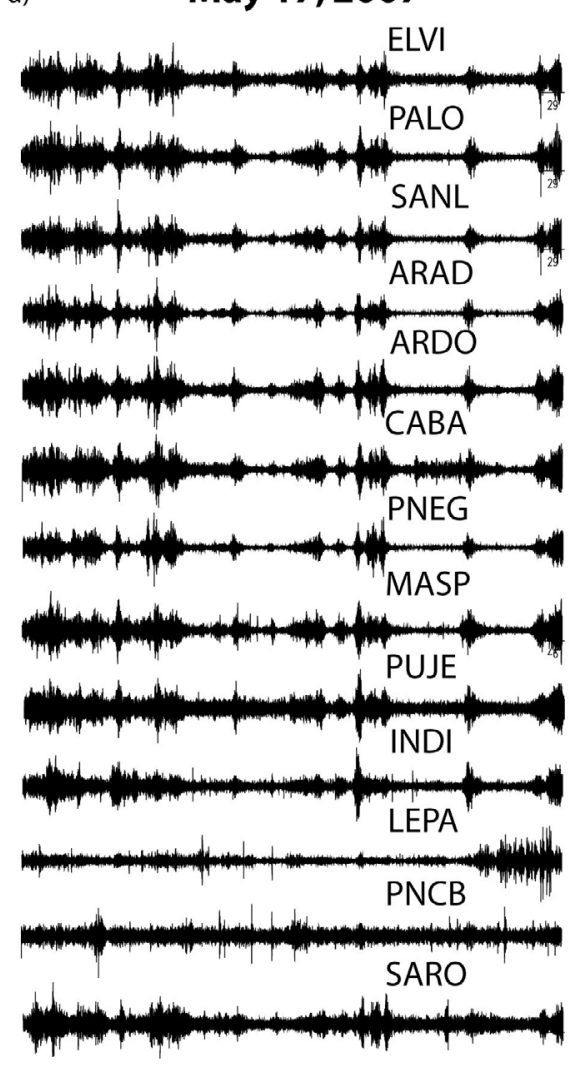

b) May 21, 2007

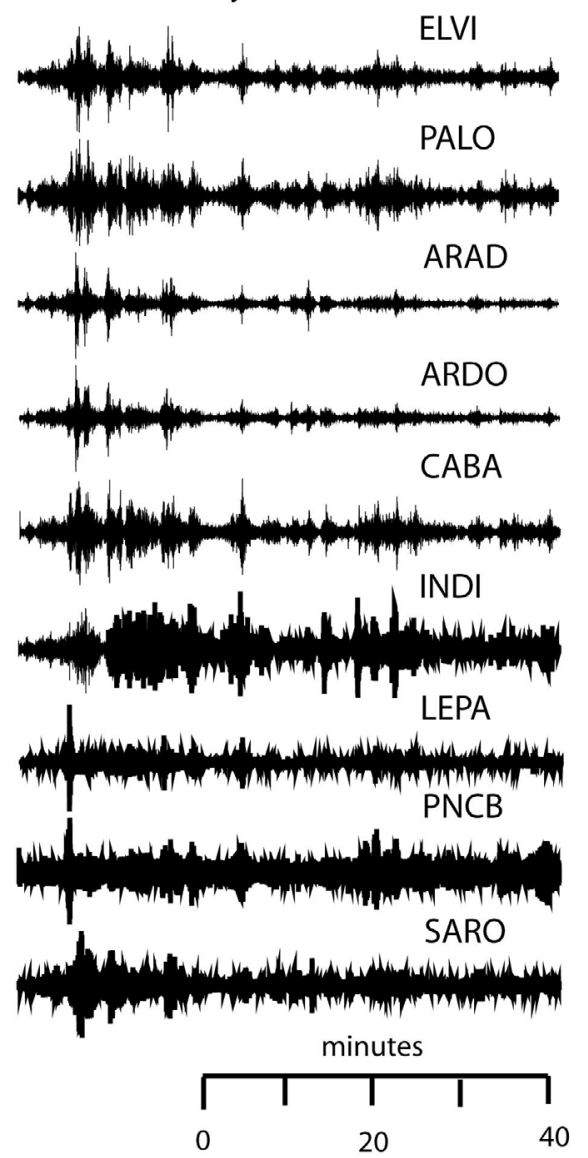

Figure 8. One hour of seismic tremor, filtered from 2-6 Hz, recorded on the east component at shortperiod boreholes (ELVI, PALO, SANL, and ARAD), broadband deep vault (ARDO), broadband (CABA, INDI, PNCB, and SARO), and short-period (PNEG, MASP, PUJE, and LEPA) surface stations for two different time periods during the 2007 tremor and slip event. (a) Julian Day (J.D.) $137 \mathrm{hr} 1$ and (b) J.D. $141 \mathrm{hr}$ 4. Tremor traces are normalized but the tremor episodes on J.D. 141 are two to three times greater in magnitude on all stations than those on J.D. 137.

and located during the first $3 \mathrm{hr}$ of tremor on 17 May 2007, using a running network autocorrelation method (Brown et al., submitted manuscript, 2009). Tremor bursts and LFEs locate in roughly the same regions, given the errors associated with the tremor envelope locations. This supports the contention of Brown et al. (submitted manuscript, 2009) that tremor beneath the Nicoya Peninsula is composed of swarms of LFEs [Shelly et al., 2007a, 2007b]. The LFEs locate on the plate interface (Brown et al., submitted manuscript, 2009) downdip of the locked seismogenic zone defined by microseismicity [DeShon et al., 2006]. Tremor or LFEs in this study could not be located in the southeast portion of the Nicoya Peninsula because of the absence of adequate station coverage: ACHA was not installed until February 2008, noise levels at the southeastern stations INDI and PNCB are four to eight times greater than the northwestern stations due to cultural and ocean noise, and LEPA had a bad clock during the time period of the 2007 TSE. However, we believe it is likely that tremor sources extend farther to the southeast than indicated in Figure 9, based on the occurrence of tremor bursts that are visible only on records from the southeast most stations LEPA and PNCB (Figure 8b).

\section{GPS Inversion}

[24] A linear inversion code [Funning et al., 2005a], based on the formulation of Okada [1985] was used to estimate the magnitude and distribution of slip on the fault plane from the surface displacement data, assuming rectangular dislocations in an elastic half space.

[25] The plate interface was modeled as three adjoining rectangular dislocation planes using the geometry described in Norabuena et al. [2004] (Figure 10). From the trench to $15 \mathrm{~km}$ depth, the interface dips at $10^{\circ}$; from $15 \mathrm{~km}$ to $38 \mathrm{~km}$ depth, the interface dips at $25^{\circ}$; and from $38 \mathrm{~km}$ to $60 \mathrm{~km}$, the interface dips at $43^{\circ}$. The strike of the fault plane is defined by the average orientation of the trench offshore, $320^{\circ}$. The length of each fault segment extends a total of $250 \mathrm{~km}$, centered on the Nicoya Peninsula to minimize possible edge effects. In order to represent distributed slip on a large fault plane, the dislocations were meshed in 


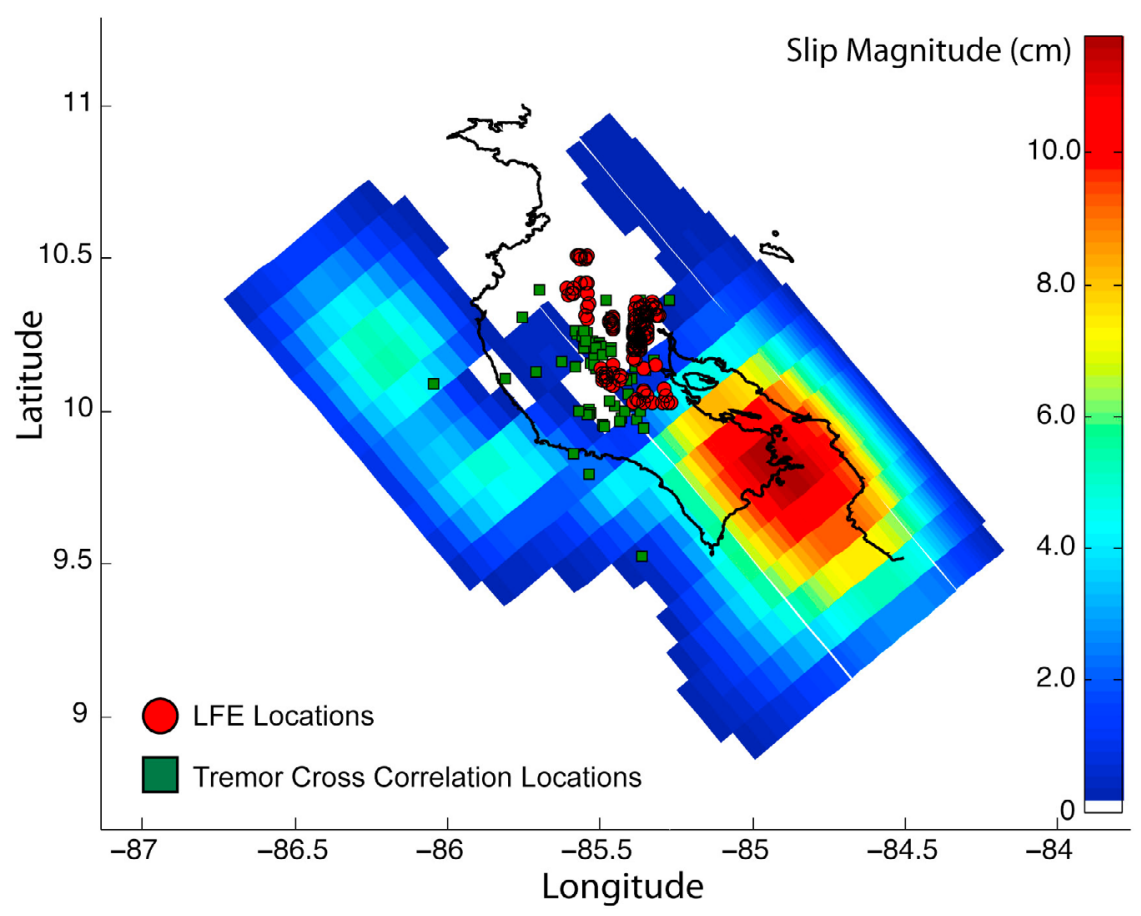

Figure 9. Locations of tremor episodes and low frequency earthquakes (LFEs) compared with slow-slip distribution.

20 equal divisions along-strike $(\sim 12.5 \mathrm{~km}$ each) and 15 equal divisions downdip ( $<6 \mathrm{~km}$ each).

[26] Resolution tests were carried out following Funning et al. [2005b] and Biggs et al. [2006]. We imposed $1 \mathrm{~m}$ of slip on one mesh segment and calculated the resulting surface displacements at each GPS station. We then inverted the resulting surface vectors for slip on the fault plane to find the inferred slip at depth. This was implemented on each mesh pixel and summed to find the along-strike and downdip resolution of the model (Figure 11).

[27] Since our data are limited and noisy, we performed inversions with constrained slip direction, solving for slip magnitude only. Since strain release events are generally opposite the convergence direction, we constrained slip direction in the model to be $10^{\circ}$ counter-clockwise of trench normal $\left(220^{\circ}\right)$, similar to the overall plate convergence (Figure 7), modified by northwest translation of the fore-arc block [DeMets, 2001]. We also tested values within $20^{\circ}$ of this slip direction; results are not sensitive within this range.

[28] To avoid geologically unreasonable slip, Laplacian smoothing is imposed. Data are inverted using a fast nonnegative least squares algorithm [Lawson and Hanson, 1974; Bro and De Jong, 1997; Funning et al., 2005a]. Inversion results for the two groups of estimated offsets (stationoptimized and network-optimized) are virtually identical. Subsequent discussion focuses on the station-optimized estimates (Table 2a). We also performed inversions with both weighted and unweighted data to ensure that our results are not biased by the error estimates, since a rigorous analysis of offset uncertainties has not been performed. GPS data

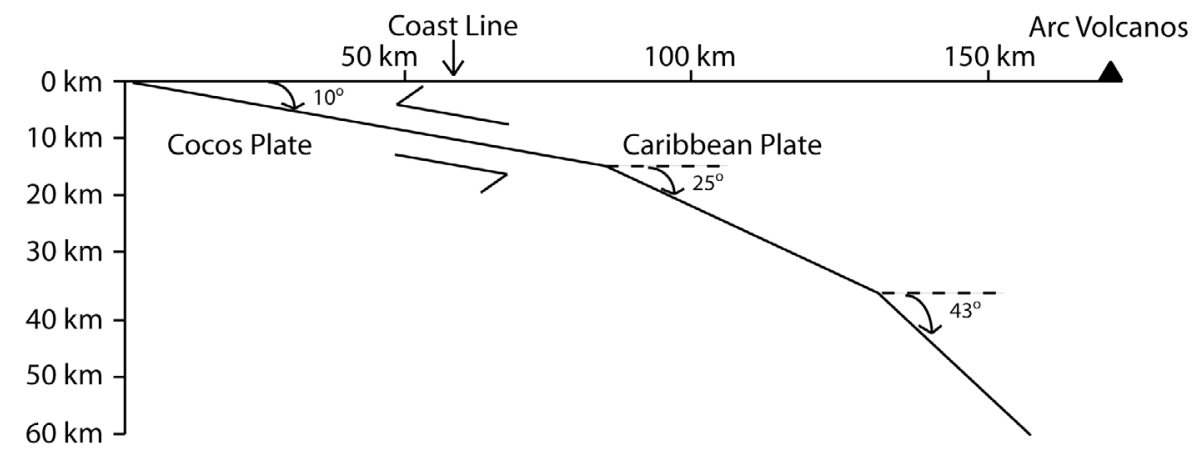

Figure 10. Fault geometry used for slip inversion [Norabuena et al., 2004]. The geometry is uniform along strike for $250 \mathrm{~km}$. From the trench to $15 \mathrm{~km}$ depth, the interface dips at $10^{\circ}$; from $15 \mathrm{~km}$ to $38 \mathrm{~km}$ depth, the interface dips at $25^{\circ}$; and from $38 \mathrm{~km}$ to $60 \mathrm{~km}$, the interface dips at $43^{\circ}$. The strike of the fault plane is defined by the average orientation of the trench offshore, $320^{\circ}$. 

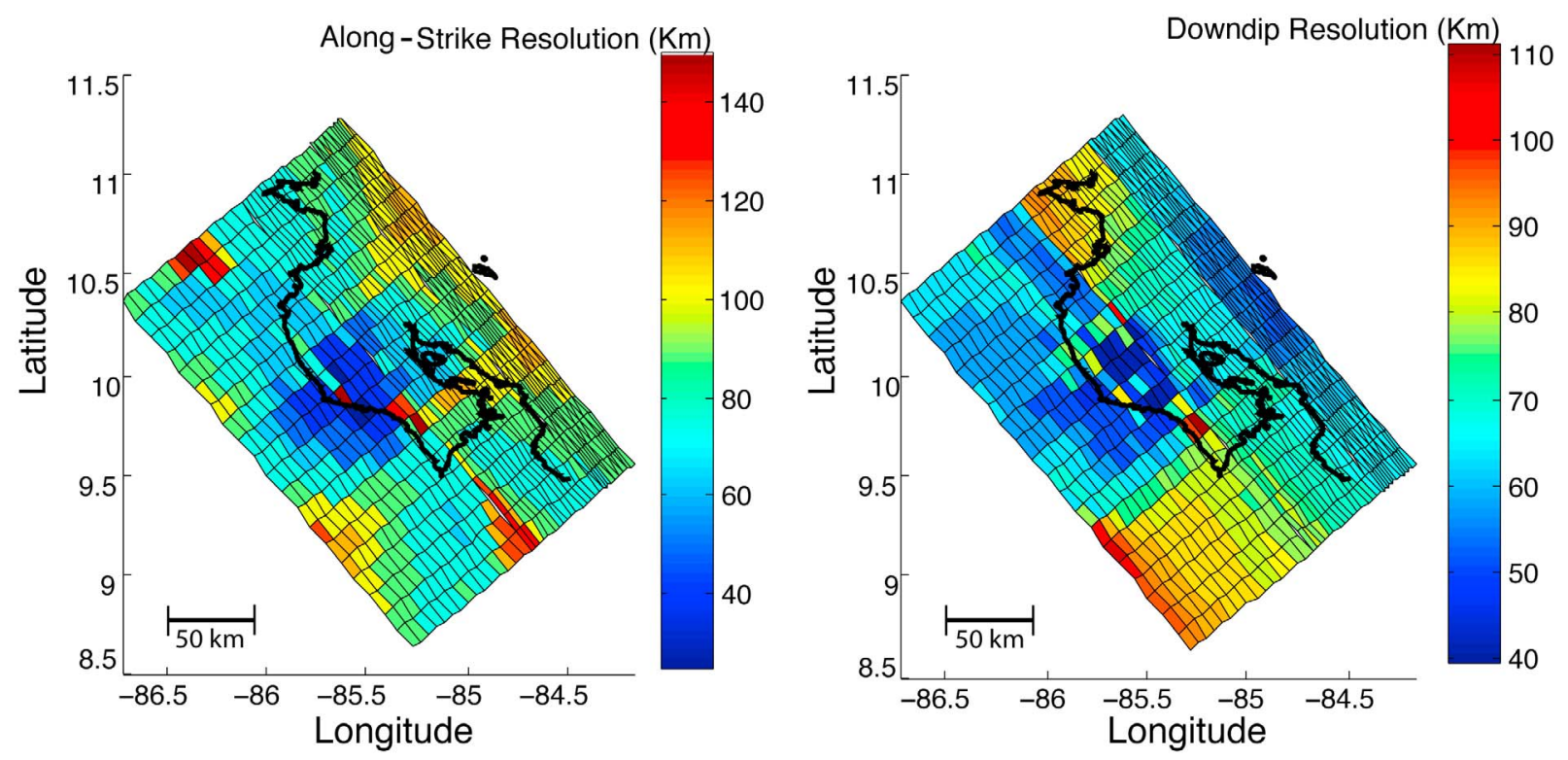

Figure 11. Along-strike and downdip model resolution results, showing minimum resolvable patch size in kilometers.

were weighted according to the estimated uncertainties shown in Table 2a. Results of the weighted and unweighted inversions are similar. Subsequent discussion focuses on results from the weighted data set.

[29] There is a well-known trade-off between the amount of smoothing applied to the inversion and the weighted root mean square (wrms) misfit of the model (Figure 12) [e.g., Biggs et al., 2009]. We show results for two end-member smoothing values that we believe span the range of plausible models (Figure 13). These give wrms misfits of $4.5 \mathrm{~mm}$ and $8.2 \mathrm{~mm}$ respectively, close to the average data noise for the north and east components respectively. The maximum displacement on the fault plane ranges from a minimum of $2.2 \mathrm{~cm}$ in the "smooth," high-misfit model to $11.8 \mathrm{~cm}$ for the "rough," low-misfit model. However the geodetic moment (related to the product of slip and area) for this

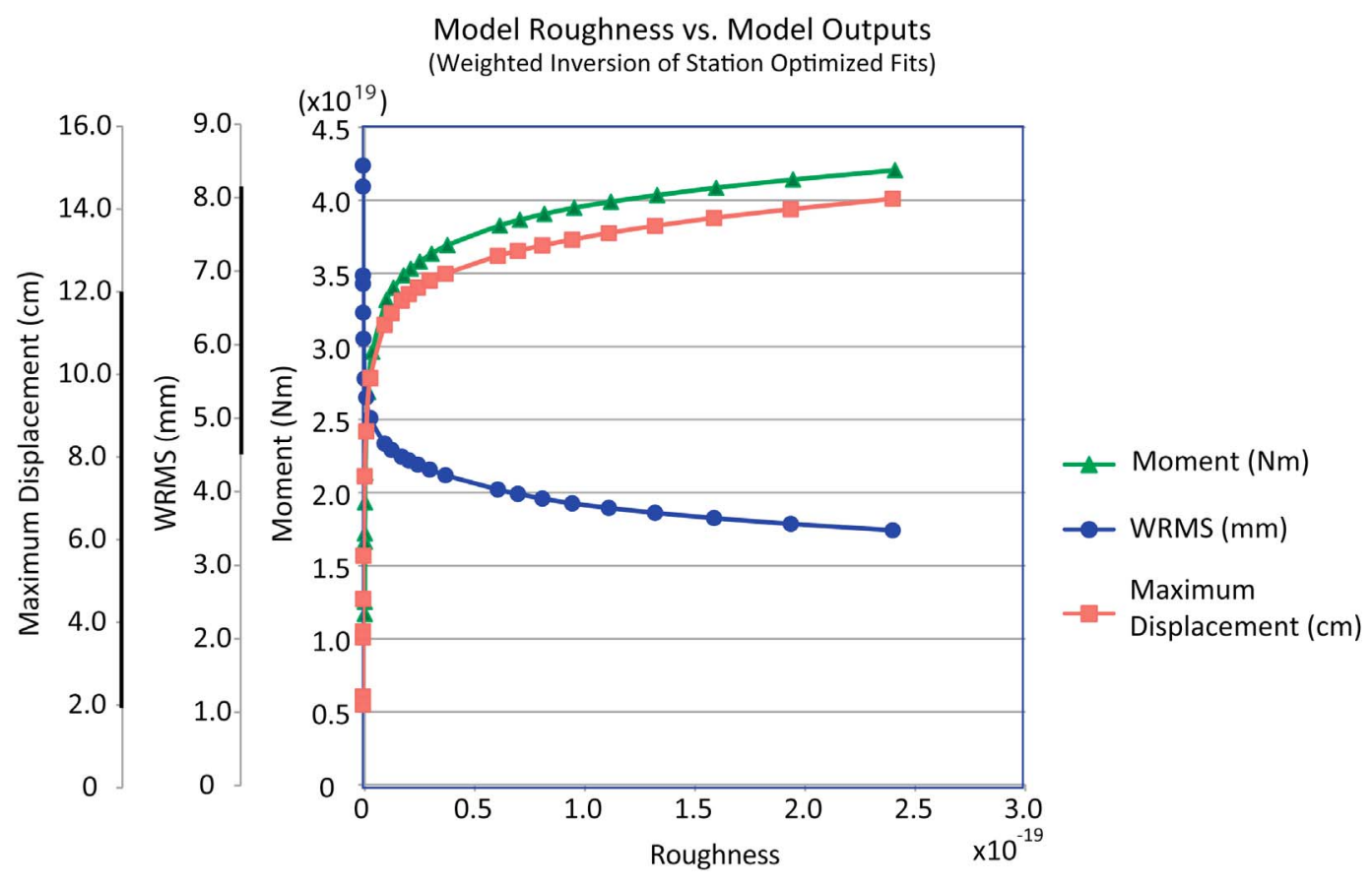

Figure 12. Inversion model roughness versus wrms, moment and magnitude of maximum displacement for weighted inversion of station-optimized fits. Bold axes indicate the range of models discussed in text. (wrms, $8.2 \mathrm{~mm}$ and wrms, $4.5 \mathrm{~mm}$ ). 

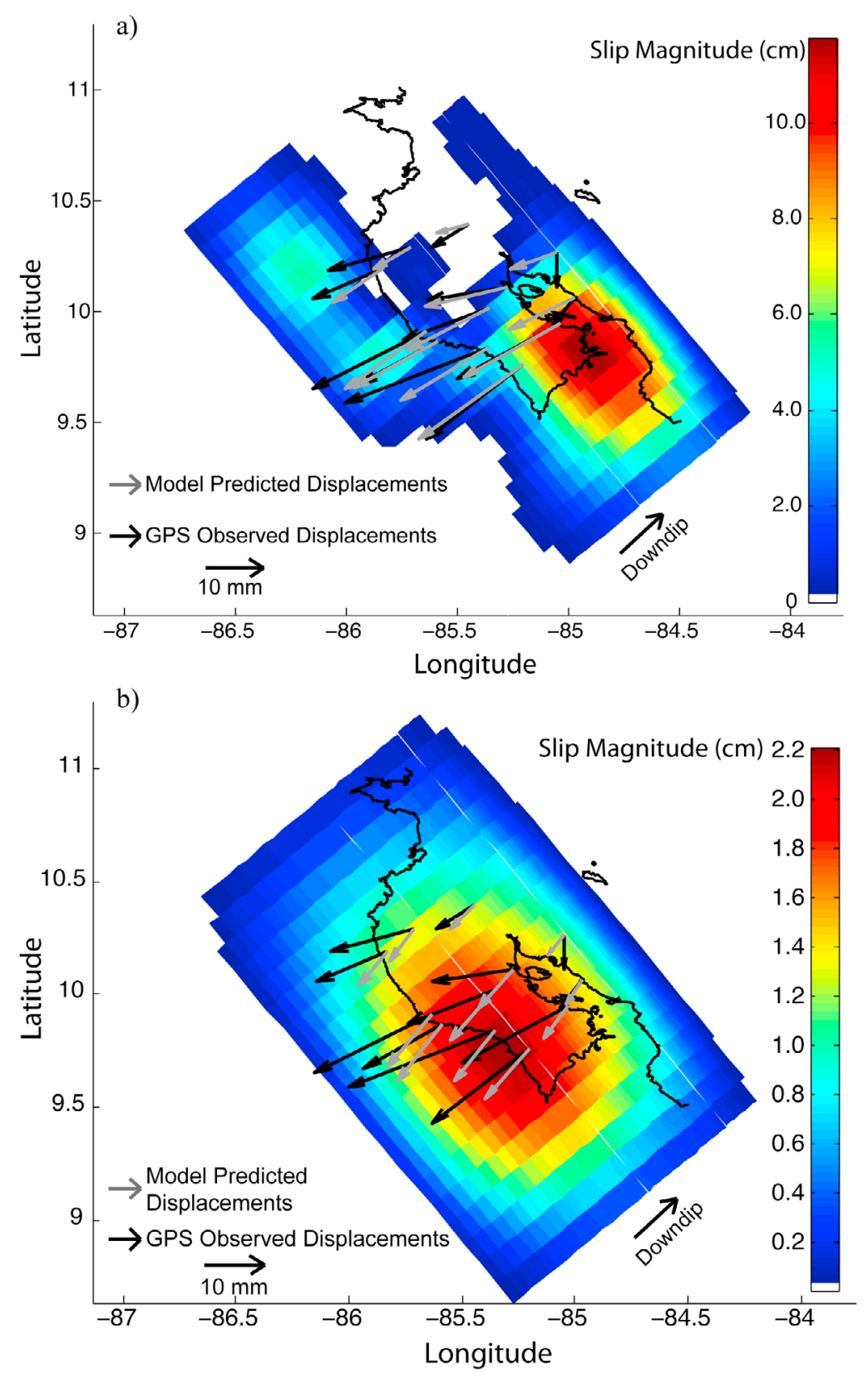

Figure 13. Predicted versus observed offsets for end member models whose parameters are marked in Figure 12 by bold axis. (a) Station-optimized timing parameters, weighted inversion; wrms, $4.5 \mathrm{~mm}$. (b) Station-optimized timing parameters; wrms, $8.2 \mathrm{~mm}$. White areas within modeled fault plane indicate negligible or no slip.

range of models varies by much less, from $1.25 \times 10^{19} \mathrm{Nm}$ to $3.49 \times 10^{19} \mathrm{Nm}$ (Figure 11 ), equivalent to moment magnitudes of 6.7 for the smooth model and 7.0 for the rough model.

[30] The geometry of slip distribution also varies with this range of models. Low-misfit models have two distinct slip patches, while higher misfit models define a single continuous patch. Average station spacing $(\sim 25 \mathrm{~km})$ is less than the size of the slip patches in the two-patch (low-misfit) model, suggesting that data density is sufficient to define these patches. Additionally, the results of our resolution tests explained above suggest that we have the resolution to identify two distinct patches of slip (Figure 11).
[31] We also tested the sensitivity of model results by selectively removing one station at a time and reinverting the remaining data subset, using the weighted inversion model (Table 3). While small variations in wrms and maximum displacement occur, the overall pattern of slip does not vary significantly, implying that our slip distribution results are robust and not dependent on data from any one station.

\section{Discussion}

\subsection{Previous Observations of Slow-Slip Events}

[32] The occurrence of tremor and slip events has been suspected in the shallow offshore region based on correlated 
Table 3. Results of Weighted Inversion, Iteratively Eliminating One Station

\begin{tabular}{ccccc}
\hline $\begin{array}{c}\text { WRMS } \\
(\mathrm{mm})\end{array}$ & $\begin{array}{c}\text { Moment } \\
(\mathrm{Nm})\end{array}$ & $\begin{array}{c}\text { Maximum } \\
\text { Displacement } \\
(\mathrm{cm})\end{array}$ & $\mathrm{M}_{\mathrm{w}}$ & $\begin{array}{c}\text { Station } \\
\text { Removed }\end{array}$ \\
\hline 4.5 & $3.49 \mathrm{E}+19$ & 11.8 & 7.0 & None \\
4.8 & $3.66 \mathrm{E}+19$ & 12.8 & 7.0 & BON2 \\
4.7 & $3.46 \mathrm{E}+19$ & 11.8 & 7.0 & ELVI \\
4.4 & $3.50 \mathrm{E}+19$ & 11.9 & 7.0 & GRZA \\
4.3 & $3.43 \mathrm{E}+19$ & 11.8 & 7.0 & HATI \\
4.7 & $3.38 \mathrm{E}+19$ & 11.5 & 7.0 & HUA2 \\
4.6 & $3.56 \mathrm{E}+19$ & 11.8 & 7.0 & INDI \\
4.6 & $3.21 \mathrm{E}+19$ & 10.8 & 6.9 & LEPA \\
4.2 & $3.43 \mathrm{E}+19$ & 12.1 & 7.0 & LMNL \\
4.6 & $3.31 \mathrm{E}+19$ & 11.7 & 6.9 & PNEG \\
4.6 & $3.56 \mathrm{E}+19$ & 11.6 & 7.0 & PUJE \\
4.3 & $3.56 \mathrm{E}+19$ & 11.9 & 7.0 & PUMO \\
3.9 & $3.68 \mathrm{E}+19$ & 12.3 & 7.0 & QSEC \\
\hline
\end{tabular}

fluid flow and seismic tremor recorded on ocean bottom instruments in 2000 [Brown et al., 2005]. The phenomenon was observed on only three out of a total of 14 OBS instruments near the base of the continental margin. LaBonte et al. [2009] used a 2-D fully coupled poroelastic finite-element model to show that the patterns of fluid flow could be matched by a dislocation on the plate interface at a depth of less than $4 \mathrm{~km}$, propagating bilaterally at an average rate of $\sim 0.5 \mathrm{~km} \mathrm{~d}^{-1}$ and lasting $20 \mathrm{~d}$ or more. In 2003 pressure gauges in ODP (Ocean Drilling Program) boreholes approximately $60 \mathrm{~km}$ offshore of the Nicoya Peninsula recorded two transient events [Davis and Villinger, 2006], also interpreted as evidence for a slow-slip event. These interpretations contrast with other studies, where slow slip is limited to the downdip frictional transition [e.g., Dragert et al., 2001; Ozawa et al., 2004; Beavan et al., 2007].

[33] A sparse network of three continuous GPS stations (INDI, HUA2, and PUJE) recorded a transient deformation event lasting approximately one month in September-October 2003 [Protti et al., 2004]. The transient displacements were nearly opposite in direction to plate convergence, and may have propagated downdip. The data were too limited to resolve details of the slip distribution. In the offshore ODP data acquired in 2003, the second pressure transient occurred about $3 \mathrm{wk}$ after initiation of the GPS recorded slow-slip event. Davis and Villinger [2006] suggested that this pressure transient was caused by slow-slip propagating updip to the trench, delayed but accompanying the onshore propagation recorded by the GPS stations. This implies that like the 2007 slow-slip event, the 2003 event may also have experienced shallow slip in the region of the updip frictional transition. Assuming that the Fall 2003 event is similar to the 2007 slow-slip event described here, and that the events repeat regularly, the slow-slip recurrence interval is $44 \mathrm{mo}$.

\subsection{Event Slow-Slip Distribution}

[34] The preferred slip distribution model has two distinct patches of slip, one centered at $\sim 6 \mathrm{~km}$ depth and one centered at $25-30 \mathrm{~km}$ depth. The significance of the updip patch in the low-misfit model (Figure 12a) is not clear, because station density in this area is low. Since the occurrence of the 2007 event, an additional coastal station (SAJU) has been installed, increasing offshore resolution in case of similar future events. The occurrence of a possible shallow slip event in 2000 [Brown et al., 2005; LaBonte et al., 2009] and pressure transients observed in ODP boreholes offshore the Nicoya Peninsula in 2003 [Davis and Villinger, 2006] and May 2007 [M. Hessemann, personal communication, 2009] suggests that the shallow slip patch in our low-misfit model may be real, and we make that assumption in the following discussion.

[35] This model shows a large slip patch with its maximum displacement near the downdip edge of the seismogenic zone ( $30 \mathrm{~km}$ depth), interpreted as the frictional transition from stick-slip to stable sliding [Schwartz and Deshon, 2007] and consistent with most observations of slow slip made at other subduction zones [Schwartz and Rokosky, 2007]. The updip patch is smaller, both in size and magnitude of slip, at $\sim 6 \mathrm{~km}$ depth. Consistent with global observations, slow slip in the Costa Rica subduction zone appears to occur in locations that are complementary to regions that remain locked.

[36] Slip migration has been observed at other subduction zones experiencing slow slip [Rogers and Dragert, 2003; Obara et al., 2004; Kao et al., 2005; Ito et al., 2007]. Although our geodetic estimates for event timing are noisy, there is some evidence that the TSE begins near GRZA and INDI at the coast and migrates away from these stations bilaterally along-strike, as well as downdip. This is consistent with the start date estimates for all of the GPS stations except LEPA. Station LEPA is exceptional in that it shows the longest event duration in the GPS data and is also located near the area of maximum slip.

[37] The separation of slow slip into an updip northern patch and a downdip southern patch (Figure 12a) may be related to different properties of subducted crust beneath each patch. For example, the northern area subducts older, smooth oceanic crust created at the East Pacific Rise (EPR), while the southern area subducts younger, rougher crust produced at the Cocos-Nazca spreading center (Figure 1) [Hey, 1977; Meschede et al., 1998; Barckhausen et al., 2001]. The two regions also experience differences in heat flow [Langseth and Silver, 1996; Fisher et al., 2003; Spinelli and Saffer, 2004; Spinelli et al., 2006; Fisher et al., 2003 Hutnak et al., 2007].

[38] The deeper patch shows peak slip at a depth of 25-30 km, near the upper plate crust-mantle boundary (continental Moho) where estimated temperatures are $\sim 250^{\circ}$ $300^{\circ} \mathrm{C}$ [Harris and Wang, 2002; Spinelli and Saffer, 2004]. On the basis of the metamorphic phase diagrams of Peacock et al. [2005] and Peacock [2009], reactions involving lowgrade metamorphic rocks (e.g., lawsonite-blueschist facies) are predicted as the slab moves through this temperature and pressure range, presumably releasing $\mathrm{H}_{2} \mathrm{O}$ and other fluids in devolatilization reactions. These processes may influence or contribute to the tremor and/or slip, e.g., by changing pore fluid pressure and effective normal stress on the plate interface [see Schwartz and Deshon, 2007; Peacock, 2009]. The northern updip slip patch presumably involves lower temperature $\left(\sim 150^{\circ}-200^{\circ} \mathrm{C}\right)$ metamorphic dewatering reactions, perhaps involving zeolites [Peacock et al., 2005].

[39] For all tested models, slip extends to the boundaries of our network. Thus, slip beyond the network boundaries may have occurred, undetected by our network, and our models should be considered minimum estimates of moment and rupture extent. 


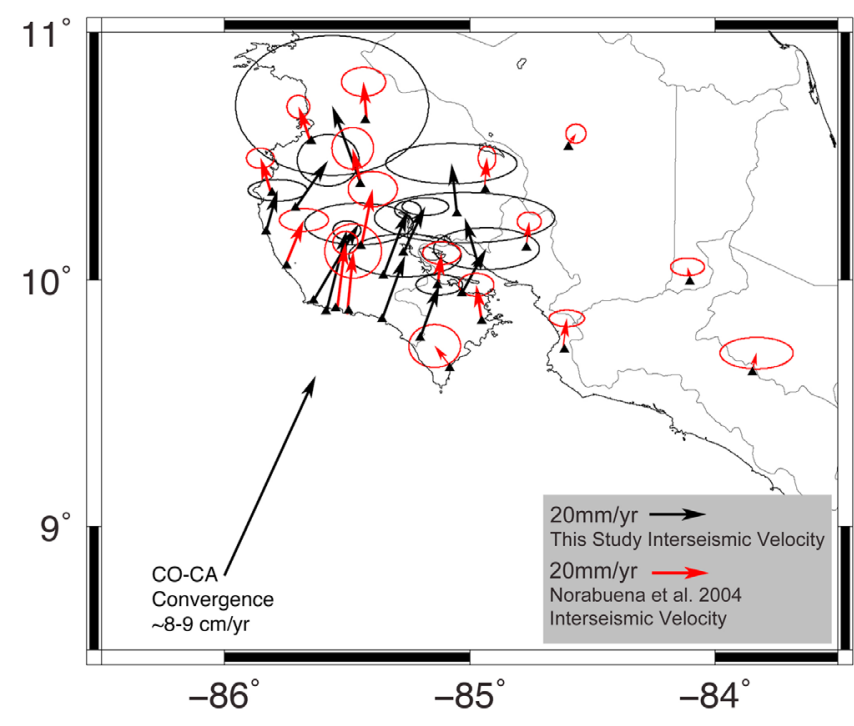

Figure 14. Interseismic velocity fields from this study (black vectors and black 95\% confidence ellipses) and from Norabuena et al. [2004] (red vectors and red 95\% confidence ellipse).

\subsection{Correlation of Slow Slip and Tremor}

[40] In general, the GPS stations closer to the coast experience slip earlier than the landward stations (Table 2). While the timing of the earliest slip initiation at the coastal stations is in good agreement with tremor commencement, both around May 17 (Julian Day 137), the earliest tremor events and the LFEs embedded within them locate farther inland. Also, the region of maximum slip is well south of the tremor and LFE locations. In other words, slip and tremor are temporally but not spatially correlated (Figure 9). The absence of tremor or LFE sources beneath the southeast portion of the peninsula, where slip attains its maximum, may reflect sparse seismic station coverage. Lower signal-to-noise ratio at the southern stations compared to those in the northwest might obscure small tremor episodes. However, since tremor sources located in the northwest portion of the peninsula are frequently recorded at the southern stations (Figure $8 \mathrm{~b}$ ) tremor originating in the southeast may simply be of smaller magnitude compared to the northwest.

[41] The tremor time series (Figure 3) shows three distinct pulses, each lasting between 4-6 d with intervening quiet periods of approximately $20 \mathrm{~d}$. The temporal resolution of the tremor is greater than the slow slip, and if tremor and slip are temporally linked, the tremor time series suggests the possibility that slow slip proceeded in three distinct phases. The first phase of tremor, occurring between May 17 and 22 (J.D. 137-142), is the most energetic, averaging over $3 \mathrm{hr}$ of tremor per day. The latter two phases (June 13-17 or J.D.164-168 and July 7-9 or J.D.188-190) consist of tremor averaging less than $1 \mathrm{hr}$ of tremor per day. The absence of a close spatial association between slow slip and LFEs within tremor is perplexing, but has been reported in northern Cascadia [Brown et al., 2009] and southwest Japan [Shelly et al., 2007a]. Detection of future slow-slip and tremor events by our enhanced Nicoya Peninsula GPS and seismic network should shed light on this poorly understood aspect of slow-slip and tremor. If tremor and slow slip are manifestations of the same process, the existence of tremor outside regions of slow-slip foci may reflect areas experiencing smaller amounts of slip, below the detection threshold of the GPS.

[42] LFEs within tremor in Costa Rica locate on or near the plate interface in the depth range of $30-45 \mathrm{~km}$, corresponding to the downdip frictional stability transition, and near the intersection of the continental Moho and down going slab [Brown et al., 2009]. This is also true of tremor at the Cascadia and southwest Japan subduction zones; however, at these locations LFEs also correlate with areas of elevated $V p / V s$ that are interpreted as regions of high fluid pressure at or near the plate interface, perhaps from dehydration reactions [Shelly et al., 2006; Audet et al., 2009]. At the Cascadia and southwest Japan subduction zones, tremor occurs where the plate boundary interface attains a temperature of $450^{\circ}-550^{\circ} \mathrm{C}$ [Hyndman and Wang, 1995; Hacker et al., 2003], the temperature at which fluids are released into the overlying crust from the basalt to eclogite reaction. In Costa Rica, tremor occurs at comparable depth but at much lower temperature between $200^{\circ}-250^{\circ} \mathrm{C}$ [Hacker et al., 2003]. Perhaps pressure, rather than temperature, is the key variable. If fluids are required for tremor generation, lower grade metamorphic dehydration reactions must also be involved.

\subsection{Strain Accumulation and Seismic Hazard}

[43] LaFemina et al. [2009] and Norabuena et al. [2004] used episodic GPS measurements to define the interseismic surface velocity field, and inverted these data for the locking pattern on the plate interface under the Nicoya Peninsula using a back slip model [Savage, 1983]. Norabuena et al. [2004] used data from 15 GPS sites, similar to the spatial sampling in this study, defining a locked patch centered at $14 \pm 2 \mathrm{~km}$ depth, locked at up to $\sim 65 \%$ of the convergence rate. Since episodic GPS data lack the temporal resolution of continuous GPS and hence miss slow-slip events, it is possible that the locked patch defined by Norabuena et al. [2004] and other studies using campaign GPS is biased in some way. The new CGPS network eliminates this temporal aliasing, and allows us to assess the nature and extent of the bias.

[44] A comparison between our new interseismic velocity field and that of Norabuena et al. [2004] is shown in Figure 14. While the network configurations used are similar, rates tend to be higher for the continuous network. For example, comparing the average velocity at two coastal stations from each network (GRZA and INDI from this study and SAMA and INDI from Norabuena et al. [2004]) the campaign measurements are lower by $12.7 \pm 11.8 \mathrm{~mm} \mathrm{yr}^{-1}$, or about $33 \%$. Thus, the patch estimated by Norabuena et al. [2004] to be locked at $65 \%$ of the convergence rate likely represented a fully locked patch, but the per cent locking was underestimated because the interseismic rate was underestimated by temporally aliased campaign GPS data (the direction of motion is much less affected, hence the pattern of locking is less affected).

[45] If the 44 mo recurrence interval that we infer for Costa Rica TSEs is correct, and given the observation window defined by the campaign measurements of Norabuena et al. [2004] (February 1994 to February 2000), it is possible that two TSEs occurred during the time frame encompassed 


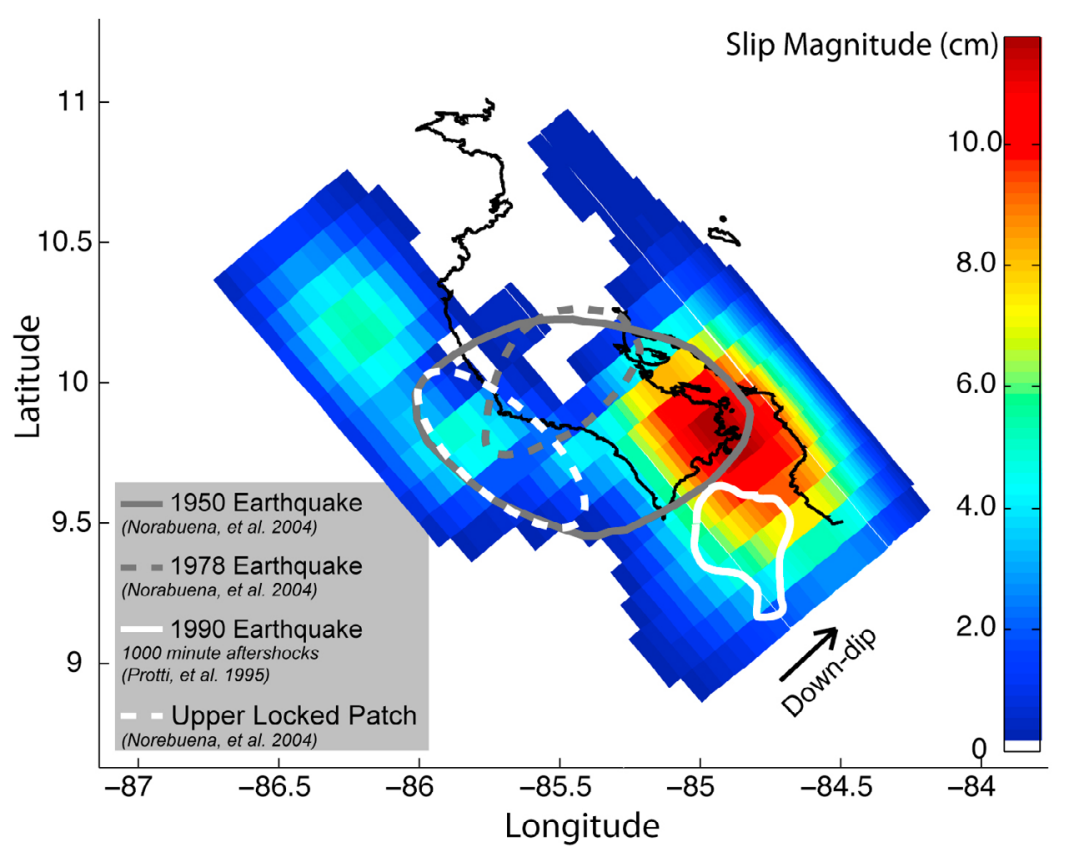

Figure 15. Comparison of the preferred slip model for the 2007 event (station-optimized timing parameters, weighted inversion; wrms, $4.5 \mathrm{~mm}$ ), rupture area of the $1950 \mathrm{M}_{\mathrm{w}}=7.7$ earthquake (gray ellipse), the $1978 \mathrm{M}_{\mathrm{w}}=7.0$ earthquake (gray dashed ellipse), and the $1990 \mathrm{M}_{\mathrm{w}}=7.0$ earthquake as defined by the 1000 min aftershocks of Protti et al. [1995] (white contour) and locked patch previously identified by Norabuena et al. [2004] (white dashed ellipse).

by the campaign data. This could account for the entirety of the $12.7 \mathrm{~mm} \mathrm{yr}^{-1}$ "deficit" in the interseismic rate estimated by the campaign measurements.

[46] A comparison of our preferred model for slip distribution beneath the Nicoya Peninsula to the updated locking pattern found in the regional study of LaFemina et al. [2009] shows that the areas of maximum slip are adjacent to areas of maximum locking. Conversely, areas of high slip are coincident with regions of lower locking. This is particularly true of model three from LaFemina et al. [2009] in which no kinematic locking constraints were imposed.

[47] There have been three $\mathrm{M}_{\mathrm{w}} \geq 7$ earthquakes in the vicinity of the Nicoya Peninsula in the last 50 yr [Protti et al., 1995]. The magnitude and rupture area of the 1950 event $\left(\mathrm{M}_{\mathrm{w}}=7.7\right)$ was significantly larger than that of the 1978 $\left(\mathrm{M}_{\mathrm{w}}=6.9\right)$ and 1990 earthquakes $\left(\mathrm{M}_{\mathrm{w}}=7.0\right)$ (Figure 15). The recurrence interval for large 1950-type events is believed to be about 50 yr based on similar events in 1852 and 1900 [Protti et al., 1995]. Norabuena et al. [2004] speculated that a future 1950 type Nicoya earthquake might be smaller than its three predecessors due to the occurrence of the 1978 event, abundant microseismicity on part of the plate interface, indicating creep, and the apparent lack of locking and strain accumulation in much of the 1950 rupture area. However, Protti et al. [2001] show that the 1978 earthquake only released $15 \%$ of the potential slip accumulated prior to the event, and therefore, its potential contribution to the reduction of the size of the next Nicoya, 1950-style event is small.

[48] The geometry, location and magnitude of slow slip will also impact future earthquakes, especially if slow-slip events occur frequently enough to release significant strain. However, a more comprehensive study is required to assess this, with better spatial constraints on the size and geometry of the TSEs, and better constraints on the frequency of these events. The Nicoya GPS and seismic network, operational since August 2009, should produce the relevant data.

\section{Conclusions}

[49] We have presented the first comprehensive geodetic and seismic evidence for the existence of tremor and slip events on the Cocos-Caribbean subduction zone segment of the Middle America Trench. We have found the following:

[50] (1) A slow-slip event, accompanied by seismic tremor, was captured on continuous GPS and seismic networks on the Nicoya Peninsula, Costa Rica, beginning in May 2007, lasting an average of $40 \mathrm{~d}$.

[51] (2) Our preferred model for the slip distribution associated with this event includes two patches of slip on the plate interface. The deeper patch has a maximum of $12 \mathrm{~cm}$ of slip, centered at 25-30 km depth, near the downdip transition of the seismogenic zone from stick-slip to stable sliding. A second, shallower patch, with a maximum of $\sim 5 \mathrm{~cm}$ of slip, occurs at about $6 \mathrm{~km}$ depth, near the updip frictional transition. These two patches are offset along strike, which may be related to different properties of the subducting crust.

[52] (3) Slow slip and tremor are temporally well correlated but lack a close spatial association.

[53] (4) In Costa Rica, slow slip and tremor occur in regions on the plate interface where thermal models predict temperatures at least $200^{\circ}$ cooler than in Cascadia and SW Japan, suggesting that temperature is not the fundamental controlling factor for slow-slip or tremor generation. However, if fluids sourced from dehydration reactions are 
required for tremor generation, then lower grade metamorphic reactions (e.g., involving lawsonite blueschist) must be important.

[54] Acknowledgments. This research was supported by several grants from NSF's MARGINS and Instrumentation and Facilities programs including OCE- 0841061 and OCE-0841091 along with EAR-0842338, EAR-0506463, EAR-0502488, EAR-0842137, EAR-0502221 and EAR0506382. The seismic borehole stations were funded by the German Science Foundation DFG as part of the SFB 574 project. This work was also made possible by a NASA Earth and Space Science Fellowship to Kimberly Outerbridge. We would like to thank Dan Sampson at UCSC and the engineers at UNAVCO for their technical support both in the lab and in the field Some of this material is based on equipment services provided by the UNAVCO Facility with support from the National Science Foundation (NSF) and National Aeronautics and Space Administration (NASA) under NSF Cooperative Agreement No. EAR-0735156. Some of the instruments used in the field program were provided by the PASSCAL facility of the Incorporated Research Institutions for Seismology (IRIS) through the PASSCAL Instrument Center at New Mexico Tech. Data collected during this experiment will be available through the IRIS Data Management Center The facilities of the IRIS Consortium are supported by the National Science Foundation under Cooperative Agreement EAR-0552316 and by the Department of Energy National Nuclear Security Administration.

\section{References}

Audet, P., et al. (2009), Seismic evidence for overpressured subducted oceanic crust and megathrust fault sealing, Nature, 457, 76-78.

Barckhausen, U., et al. (2001), Revised tectonic boundaries in the Cocos Plate off Costa Rica: Implications for the segmentation of the convergent margin and for plate tectonic models, J. Geophys. Res., 106(B9), 19,207-19,220, doi:10.1029/2001JB000238.

Beavan, J., et al. (2007), Slow slip events on the Hikurangi subduction interface, New Zealand, in Dynamic Planet: Monitoring and Understanding a Dynamic Planet with Geodetic and Oceanographic Tools. edited by P. Tregoning and C. Rizos, pp. 438-444, Springer, New York

Biggs, J., et al. (2006), Fault identification for buried strike-slip earthquakes using InSAR: The 1994 and 2004 Al Hoceima, Morocco earthquakes, Geophys. J. Int., 166, 1347-1362.

Biggs, J., D. P. Robinson, T. H. Dixon (2009) The 2007 Pisco, Peru, earthquake (M8.0): seismology and geodesy, Geophys. J. Int., 176, 657-669. Blewitt, G. (2008), Fixed point theorems of GPS carrier phase ambiguity resolution and their application to massive network processing: Ambizap, J. Geophys. Res., 113, B12410, doi:10.1029/2008JB005736.

Blewitt, G., and C. Kreemer (2007), Mega-network GPS solutions: Producing a consistent, global-scale, and high-resolution view of plate tectonic stability, rotation, and deformation, Eos Trans. $A G U, 88(52)$, Fall Meet. Suppl., Abstract [G21B-0501].

Bro, R., and S. De Jong (1997), A fast non-negativity-constrained least squares algorithm, J. Chemometrics, 11(5), 393-401

Brown, K., et al. (2005), Correlated transient fluid pulsing and seismic tremor in the Costa Rica subduction zone, Earth and Planet. Sci. Lett. $238,189-203$.

Brown, J. R., et al. (2008), An autocorrelation method to detect low frequency earthquakes within tremor, Geophys. Res. Lett., 35, L16305, doi:10.1029/2008GL034560.

Brown, J. R., et al. (2009), Deep low-frequency earthquakes in tremor localize to the plate interface in multiple subduction zones, Geophys. Res. Lett., 36, L19306, doi:10.1029/2009GL040027.

Brudzinski, M., and R. M. Allen (2007), Segmentation in episodic tremor and slip all along Cascadia, Geology, 35(10), 907-910.

Brudzinski, M., et al. (2007), Slow slip transients along the Oaxaca subduction segment from 1993 to 2007, Geophys. J. Int., 171, 523-538.

Davis, E. E., and H. W. Villinger (2006), Transient formation fluid pressures and temperatures in the Costa Rica forearc prism and subducting oceanic basement: CORK monitoring at ODP sites 1253 and 1255, Earth and Planet. Sci. Lett., 245, 232-244.

DeMets, C. (2001), A new estimate for present-day Cocos-Caribbean Plate motion: Implications for slip along the Central American Volcanic Arc, Geophys. Res. Lett., 28(21), 4043-4046, doi:10.1029/2001GL013518.

DeMets, C., et al. (1994), Effect of recent revisions to the geomagnetic reversal time scale on estimates of current plate motions, Geophys. Res. Lett., 21(20), 2191-2194, doi:10.1029/94GL02118.

DeShon, H. R., et al. (2003), Seismic zone structure of the southern Middle America Trench, Costa Rica, J. Geophys. Res., 108(B10), 2491, doi:10.1029/2002JB002294.
DeShon, H. R., et al. (2006), Seismogenic zone structure beneath the Nicoya Peninsula, Costa Rica, from three-dimensional local earthquake P- and S-wave tomography, Geophys. J. Int., 164, 104-124.

Dixon, T. H., et al. (2000), Present-day motion of the Sierra Nevada block and some tectonic implications for the basin and range province, North American Cordillera, Tectonics, 19(1), 1-24, doi:10.1029/1998TC001088.

Douglas, A., et al. (2005), Slow slip on the northern Hikurangi subduction interface, New Zealand, Geophys. Res. Lett., 32, L16305, doi:10.1029/ 2005GL023607.

Dragert, H. (2007), Mediating plate convergence, Science, 315, 471-472.

Dragert, H., et al. (2001), A silent slip event on the deeper Cascadia subduction interface, Science, 292(5521), 1525-1528.

Fisher, A. T., et al. (2003), Abrupt thermal transition reveals hydrothermal boundary and role of seamounts within the Cocos Plate, Geophys. Res. Lett., 30(11), 1550, doi:10.1029/2002GL016766.

Franco, S. I., et al. (2005), Propagation of the 2001-2002 silent earthquake and interplate coupling in the Oaxaca subduction zone, Mexico, Earth Planets Space, 54, 973-985.

Funning, G. J., et al. (2005a), The 1998 Aiquile, Bolivia earthquake: A seismically active fault revealed with InSAR, Earth Planet. Sci. Lett., $232(1-2), 39-49$

Funning, G. J., et al. (2005b), Surface displacements and source parameters of the 2003 Bam (Iran) earthquake from Envisat advanced synthetic aperture radar imagery, J. Geophys. Res., 110, B09406, doi:10.1029/ 2004JB003338.

Guzman-Speziale, M. (2001), Active seismic deformation in the grabens of northern Central America and its relationship to the relative motion of the North American-Caribbean plate boundary, Tectonophysics, 337, 39-51.

Hacker, B. R., et al. (2003), Subduction factory - 2. Are 256 intermediatedepth earthquakes in subducting slabs linked to metamorphic dehydration 257 reactions?, J. Geophys. Res., 108 (B1), 2030, doi:10.1029 2001JB001129.

Harris, R. N., and K. Wang (2002), Thermal models of the Middle America Trench at the Nicoya Peninsula, Costa Rica, Geophys. Res. Lett., 29(21), 2010, doi:10.1029/2002GL015406.

Hey, R. (1977), Tectonic evolution of the Cocos-Nazca spreading center, Geol. Soc. Am. Bull., 1977, 1404-1420.

Hirose, H., and K. Obara (2005), Repeating short- and long-term slow slip events with deep tremor activity around the Bungo channel region, southwest Japan, Earth Planets and Space, 57(10), 961-972.

Hirose, H., and K. Obara (2006), Short-term slow slip and correlated tremor episodes in the Tokai region, central Japan, Geophys. Res. Lett., 3, L17311, doi:10.1029/2006GL026579.

Hirose, H., et al. (1999), A slow thrust slip event following the two 1996 Hyuganada earthquakes beneath the Bungo Channel, southwest Japan, Geophys. Res. Lett., 26(21), 3237-3240, doi:10.1029/1999GL010999.

Hutnak, M., et al. (2007), The thermal state of 18-24 Ma upper lithosphere subducting below the Nicoya Peninsula, northern Costa Rica margin, in The Seismogenic Zone of Subduction Thrust Faults, edited by T. Dixon and J. C. Moore, pp. 86-122, Columbia University Press, New York.

Hyndman, R. D., and K. Wang (1995), The rupture zone of Cascadia great earthquakes from current deformation and the thermal regime, J. Geophys. Res., 100(B11), 22,133-22,154, doi:10.1029/95JB01970.

Igarashi, T., et al. (2003), Repeating earthquakes and interplate aseismic slip in the northeastern Japan subduction zone, J. Geophys. Res., 108(B5), 2249, doi:10.1029/2002JB001920.

Iinuma, T., et al. (2004), Inter-plate coupling in the Nicoya Peninsula, Costa Rica, as deduced from a trans-peninsula GPS experiment, Earth Planet. Sci. Lett., 223, 203-212.

Ito, Y., et al. (2007), Slow earthquakes coincident with episodic tremors and slow slip events, Science, 315, 503-506.

Kao, H., et al. (2005), A wide depth distribution of seismic tremors along the northern Cascadia margin, Nature, 436, 841-844.

Kato, N. (2003), A possible model for large preseismic slip on a deeper extension of a seismic rupture plane, Earth Planet. Sci. Lett., 216, 17-25.

Klein, F. W. (2007), User's Guide to HYPOINVERSE-2000, a FORTRAN Program to Solve for Earthquake Locations and Magnitudes, version 1.1 (US), 2-171.

Kostoglodov, V., S. K. Singh, J. A. Santiago, S. I. Franco, K. M. Larson, A. R. Lowry, and R. Bilham (2003), A large silent earthquake in the Guerrero seismic gap, Mexico, Geophys. Res. Lett., 30(15), 1807, doi:10.1029/2003GL017219.

LaBonte, A. L., et al. (2009), Hydrologic detection and finite element modeling of a slow slip event in the Costa Rica prism toe, J. Geophys. Res., 114, B00A02, doi:10.1029/2008JB005806

LaFemina, P., et al. (2009), Fore-arc motion and Cocos Ridge collision in Central America, Geochem. Geophys. Geosyst., 10, Q05S14, doi:10.1029/2008GC002181. 
Langseth, M. G., and E. A. Silver (1996), The Nicoya Convergent MarginA region of exceptionally low heat flow, Geophys. Res. Lett., 23(8), 891-894, doi:10.1029/96GL00733.

Larson, K. M., et al. (2004), Crustal deformation measurements in Guerrero, Mexico, J. Geophys. Res., 109, B04409, doi:10.1029/2003JB002843.

Larson, K. M., et al. (2007), The 2006 aseismic slow slip event in Guerrero, Mexico: New results from GPS, Geophys. Res. Lett., 34, L13309, doi:10.1029/2007GL029912.

Lawson, C. L., and R. J. Hanson (1974), Solving Least-Squares Problems. Prentice-Hall, New York.

Lowry, A. R., et al. (2001), Transient fault slip in Guerrero, southern Mexico, Geophys. Res. Lett., 28(19), 3753-3756, doi:10.1029/2001GL013238.

Lundgren, P., et al. (1999), Seismic cycle and plate margin deformation in Costa Rica: GPS observations from 1994 to 1997, J. Geophys. Res., 104(B12), 28,915-28,926, doi:10.1029/1999JB900283.

Mao, A., et al. (1999), Noise in GPS coordinate time series, J. Geophys. Res., 104(B2), 2797-2816, doi:10.1029/1998JB900033.

Marshall, J. S., et al. (2000), Central Costa Rica deform belt: Kinematics of diffuse faulting across the western Panama block, Tectonics, 19(3), 468-492, doi:10.1029/1999TC001136.

McCaffrey, R., et al. (2008), Slow slip and frictional transition at low temperatures at the Hikurangi subduction zone, Nat. Geosci., 1, 316-320.

McClausland, W., et al. (2005), Temporal and spatial occurrence of deep non-volcanic tremor: From Washington to northern California, Geophys. Res. Lett., 32, L24311, doi:10.1029/2005GL024349.

Melbourne, T. I., et al. (2005), Extent and duration of the 2003 Cascadia slow earthquake, Geophys. Res. Lett., 32, L04301, doi:10.1029/2004GL021790.

Meschede, M., et al. (1998), Extinct spreading Cocos Ridge, Terra Nova, 10, 211-216.

Miller, M. M., et al. (2002), Periodic slow earthquakes from the Cascadia subduction zone, Science, 295(5564), 2423.

Newman, A. V., S. Y. Schwartz, V. Gonzalez, H. R DeShon, J. M. Protti, and L. M. Doorman (2002), Along-strike variability in the seismogenic zone below Nicoya Peninsula, Costa Rica, Geophys. Res. Lett., 29(20), 1977, doi:10.1029/2002GL015409.

Norabuena, E., et al. (2004), Geodetic and seismic constraints on seismogenic zone processes in Costa Rica, J. Geophys. Res., 109, B11403, doi:10.1029/2003JB002931.

Obara, K. (2002), Nonvolcanic deep tremor associated with subduction in southwest Japan, Science, 296(5573), 1679-1681.

Obara, K., et al. (2004), Episodic slow slip events accompanied by nonvolcanic tremors in southwest Japan subduction zone, Geophys. Res. Lett., 31, L23602, doi:10.1029/2004GL020848.

Okada, Y. (1985), Surface deformation due to shear and tensile faults in a half-space, Bull. Seimol. Soc. Am., 75, 1135-1154.

Ozawa, S., et al. (2001), Time-dependent inversion study of the slow thrust event in the Nankai trough subduction zone, southwestern Japan, J. Geophys. Res., 106(B1), 787-802.

Ozawa, S., et al. (2002), Detection and monitoring of ongoing aseismic slip in the Tokai Region, Central Japan, Science, 298(5595), 1009-1012.

Ozawa, S., et al. (2003), Characteristic silent earthquakes in the eastern part of the Boso peninsula, Central Japan, Geophys. Res. Lett., 30(6), 1283, doi:10.1029/2002GL016665.

Ozawa, S., et al. (2004), Aseismic slip and low-frequency earthquakes in the Bungo channel, southwestern Japan, Geophys. Res. Lett., 31, L07609, doi:10.1029/2003GL019381.

Ozawa, S., et al. (2007), Spatiotemporal evolution of aseismic interplate slip between 1996 and 1998 and between 2002 and 2004 in Bungo channel, southwest Japan, J. Geophys. Res., 112, B05409, doi:10.1029/ 2006JB004643.

Payero, J. S., et al. (2008), Nonvolcanic tremor observed in the Mexican subduction zone, Geophys. Res. Lett., 35, L07305, doi:10.1029/ 2007GL032877.

Peacock, S. M. (2009), Thermal and metamorphic environment of subduction zone episodic tremor and slip, J. Geophys. Res., 114, B00A07, doi:10.1029/2008JB005978.

Peacock, S. M., and K. Wang (1999), Seismic consequences of warm versus cool subduction metamorphism: Examples from Southwest and Northeast Japan, Science, 286, 937-939.

Peacock, S. M., et al. (2002), Thermal structure and metamorphism of subducting oceanic crust: Insight into Cascadia intraslab earthquakes, in The Cascadia Subduction Zone and Related Subduction SystemsSeismic Structure, Intraslab Eathquakes and Processes, and Earthquake Hazards, edited by S. Kirby et al., pp. 123-126, USGS, Menlo Park.

Peacock, S. M., et al. (2005), Thermal structure of the Costa Rica - Nicaragua subduction zone, Phys. Earth Planet. Inter., 149, 187-200.

Protti, M., et al. (1995), The March 25, 1990 (Mw = 7.0, ML =6.8), earthquake at the entrance of the Nicoya Gulf, Costa Rica: Its prior activity, foreshocks, aftershocks, and triggered seismicity, J. Geophys. Res., 100(B10), 20,345-20,358, doi:10.1029/94JB03099.

Protti, M., F. Güendel, and E. Malavassi (2001), Evaluación del Potencial Sísmico de la Península de Nicoya, Editorial FUNA, Universidad Nacional, $143 \mathrm{p}$.

Protti, M., et al. (2004), A creep event on the shallow interface of the Nicoya Peninsula, Costa Rica seismogenic zone, EOS Trans. AGU, 85 (87), Fall Meet. Suppl., Abstract [S41D-07].

Rogers, G., and H. Dragert (2003), Episodic tremor and slip on the Cascadia subduction zone: The chatter of silent slip, Science, 300(5627), 1942-1943.

Savage, J. C. (1983), A dislocation model of strain accumulation and release at a subduction zone, J. Geophys. Res., 88(B6), 4984-4996, doi:10.1029/JB088iB06p04984.

Schwartz, S. Y., and H. R. Deshon (2007), Distinct updip limits to geodetic locking and microseismicity at the northern Costa Rica seismogenic zone: Evidence for two mechanical transitions, in The Seismogenic Zone of Subduction Thrust Faults, edited by T. Dixon and J. C. Moore, pp. 576-599, Columbia University Press, New York.

Schwartz, S. Y., and J. M. Rokosky (2007), Slow slip events and seismic tremor at circum pacific subduction zones, Rev. Geophys., 45, RG3004, doi:10.1029/2006RG000208.

Sella, G. F., T. H. Dixon, and A. Mao (2002), REVEL: A model for recent plate velocities from space geodesy, J. Geophys. Res., 107(B4), 2081, doi:10.1029/2000JB000033.

Shelly, D. R., et al. (2006), Low-frequency earthquakes in Shikoku, Japan, and their relationship to episodic tremor and slip, Nature, 442(7099), $188-191$.

Shelly, D. R., et al. (2007a), Non-volcanic tremor and low-frequency earthquake swarms, Nature, 446, 305-307.

Shelly, D. R., et al. (2007b), Complex evolution of transient slip derived from precise tremor locations in western Shikoku, Japan, Geochem. Geophys. Geosyst., 8, Q10014, doi:10.1029/2007GC001640.

Spinelli, G. A., and D. M. Saffer (2004), Along-strike variations in underthrust sediment dewatering on the Nicoya margin Costa Rica related to the updip limit of seismicity, Geophys. Res. Lett., 31, L04613, doi:10.1029/2003GL018863.

Spinelli, G. A., D. M. Saffer, and M. B. Underwood (2006), Hydrogeological responses to three-dimensional temperature variability, Costa Rica subduction margin, J. Geophys. Res., 111, B04403, doi:10.1029/ 2004JB003436.

Szeliga, W., et al. (2008), GPS constraints on 34 slow slip events within the Cascadia subduction zone, 1997-2005, J. Geophys. Res., 113, B04404, doi:10.1029/2007JB004948.

Wech, A. G., and K. C. Creager (2008), Automated detection and location of Cascadia tremor, Geophys. Res. Lett., 35, L20302, doi:10.1029/ 2008 GL035458.

Zumberge, J. F., et al. (1997), Precise point positioning from the efficient and robust analysis of GPS data from large networks, J. Geophys. Res., 102(B3), 5005-5017, doi:10.1029/96JB03860.

J. Biggs, NCEO Department of Earth Sciences, University of Oxford, Parks Road, Oxford OX1 3PR, UK.

T. H. Dixon and K. C. Outerbridge, Rosenstiel School of Marine and Atmospheric Science, University of Miami, 4600 Rickenbacker Causeway, Miami, FL 33132, USA. (kouterbridge@rsmas.miami.edu)

V. Gonzalez and M. Protti, Universidäd Nacional, Heredia, D-2409 Costa Rica.

W. Rabbel and M. Thorwart, Christian-Albrechts-Universitat, 24098 Kiel, Germany.

S. Y. Schwartz and J. I. Walter, University of California, 1156 High St., Santa Cruz, CA 95064, USA. 